AEC Contract No. W-7405-eng-92

\title{
IRRADIATION OF SNAP SYSTEM ELECTRICAL DEVICES IN A HIGH-TEMPERATURE VACUUM ENVIRONMENT
}

\author{
by
}

Sam J. Basham

William J. Zielenbach

H. Thomas Gruber

Joseph P. Allgeier

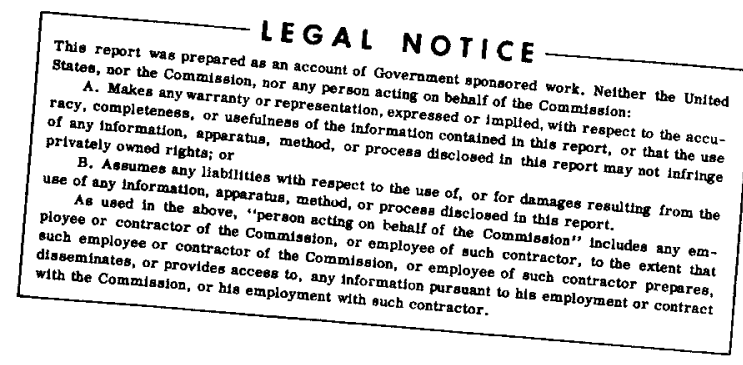

\section{(}

4. THE PUBLIC IS APPROBTAINED, RELEASE $\%$

\begin{abstract}
April 5, 1965
ARE ON FILE IN THE RECEIVIROCEDURES
\end{abstract}

BATTELLE MEMORLAL INSTITUTE

505 King Avenue

Columbus, Ohio 43201 


\section{DISCLAIMER}

This report was prepared as an account of work sponsored by an agency of the United States Government. Neither the United States Government nor any agency Thereof, nor any of their employees, makes any warranty, express or implied, or assumes any legal liability or responsibility for the accuracy, completeness, or usefulness of any information, apparatus, product, or process disclosed, or represents that its use would not infringe privately owned rights. Reference herein to any specific commercial product, process, or service by trade name, trademark, manufacturer, or otherwise does not necessarily constitute or imply its endorsement, recommendation, or favoring by the United States Government or any agency thereof. The views and opinions of authors expressed herein do not necessarily state or reflect those of the United States Government or any agency thereof. 


\section{DISCLAIMER}

Portions of this document may be illegible in electronic image products. Images are produced from the best available original document. 
INTRODUCTION • •

IRRADIATION SYSTEM

Facility at Reactor . . . . . . . . . . . . . . . . . . . . 2

Specimen Assemblies . . . . . . . . . . . . . . . . . . . 44

HF-6 Assembly . . . . . . . . . . . . . . 5

$\mathrm{HF}-7$ Assembly . . . . . . . . . . . . . . . 5

FLUX-LEVEL CONSIDERATIONS AND MEASUREMENTS . • • • • • • . $\quad 8$

Background . . . . . . . . . . . . . . . . . . 8

Mock-up Measurement Techniques and Data . . . . . . . . . 99

Neutron Spectra . . . . . . . . . . . . . . . . . 11

Neutron-Flux Distribution . . . . . . . . . . . . . 11

Gamma-Exposure-Rate Distribution . . . . . . . . . 15

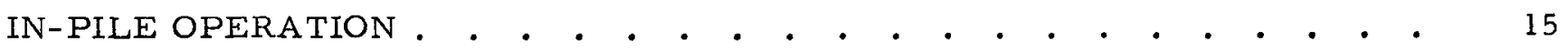

Experiment HF-6 • . . . . . . . . . . . . . . . . . . 15

Operation . . . . . . . . . . . . . . . . 15

Temperature Levels . . . . . . . . . . . . . 15

Vacuum Levels . . . . . . . . . . . . . . . . . 18

Electrical Measurements . . . . . . . . . . . . . 18

Experiment HF-7 • . . . . . . . . . . . . . . . . . . 21

Operation . . . . . . . . . . . . . . . . . . 21

Temperature Levels . . . . . . . . . . . . . . . 21

System Vacuum . . . . . . . . . . . . . . . 34

Electrical Measurements . . . . . . . . . . . . . 34

RTD Thermal Cycling . . . . . . . . . . . . . . 38

EABRD Actuation . . . . . . . . . . . . . . . . 40

POSTIRRADIATION DOSIMETRY . . . . . . . . . . . . . . . . . . 41

In-Pile Measurement Techniques and Data . . . . . . . . . . . 41

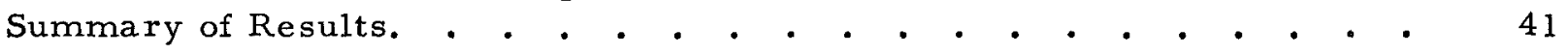

APPENDIX

RADIATION EXPOSURES OF INDIVIDUAL COMPONENTS OF EXPERIMENTS $\mathrm{HF}-6$ AND HF-7 . . . . . . . . . . . . . . . . . . . . . A-1 


\title{
IRRADIATION OF SNAP SYSTEM ELECTRICAL DEVICES \\ IN A HIGH-TEMPERATURE VACUUM ENVIRONMENT
}

by

Sam J. Basham

W. J. Zielenbach

H. Thomas Gruber

J. P. Allgeier

\section{ABSTRACT}

\begin{abstract}
A series of electrical devices was exposed to an integrated fast-neutron exposure of about 5 to $8 \times 10^{18} \mathrm{n} / \mathrm{cm}^{2}$ in a high-vacuum environment $\left(<10^{-5}\right.$ torr $)$ with specimen temperatures maintained at specified levels in the 650 to $1050 \mathrm{~F}$ range to obtain radiation-effects data for the Atomics International SNAP program Two separate experiments were conducted; 12 specimens were exposed in the first (Experiment HF-6) and 16 in the second (Experiment $H F-7$ ). Nuclear environments were measured by extensive dosimetry. The electrical characteristics of the specimens were measured during the irradiation. These data were transmitted to Atomics International for use in SNAP program systems development.
\end{abstract}

\section{INTRODUCTION}

Under the sponsorship of Atomics International, Division of North American Aviation, Inc., Battelle has been conducting a series of radiation-damage experiments at the Battelle Research Reactor (BRR). Part of the program has consisted of the irradiation of selected electronic and mechanical devices and materials under the following conditions:

$$
\begin{aligned}
& \text { Temperature }-500 \text { to } 1100 \mathrm{~F} \\
& \text { Integrated fast-neutron exposure }- \text { greater than } 1 \times 10^{19} \mathrm{n} / \mathrm{cm}^{2} \\
& \text { Vacuum level }-1 \times 10^{-5} \text { torr or below. }
\end{aligned}
$$

The two experiments described herein constitute part of this support for the SNAP$10 \mathrm{~A}$ program and are designated HF (high-flux) -6 and -7 . Previous experiments in the HF series are described in recent reports designated BMI-X-310 and BMI-X-10109. Another part of the program consists of five in-vacuum irradiations at a nominal $150 \mathrm{~F}$ to total integrated fast-neutron exposures of $1 \times 10^{16} \mathrm{n} / \mathrm{cm}^{2}$. These experiments are described in Report BMI-X-290.

Generally, each of the two experiments consisted of the following phases:

(1) Selection by Atomics International of components to be irradiated in each experiment and the specification of experimental conditions 
(2) Reactor flux mapping to determine neutron distribution and gamma exposure rates.

(3) Experiment design

(4) Experiment assembly and installation at the reactor in the previously modified high-vacuum system

(5) Experiment operations including continuous temperature monitoring of the specimens and periodic sampling of the vacuum level and specimen performance to establish damage thresholds and ascertain the degradation rates after these thresholds were exceeded

(6) Postirradiation evaluation of experiment dosimetry.

This report covers all aspects of the experiment. Typical performance data are presented without interpretation. The irradiated samples were examined at the Battelle Hot Cell Facility, and the results are reported separately.

\section{IRRADIATION SYSTEM}

Facility at Reactor

The high-vacuum facility at the BRR employed in these two experiments is illustrated in Figure 1. It consists of a test section (8-in. aluminum pipe), an 8-in, tee section with $6-$ in. side arm, a lead tube (4-in. aluminum pipe), an ionization-gage housing and lead tube (2-1/2-in. pipe), a 6-in. vacuum line (aluminum) to the pool surface, and a 6-in. oil diffusion pump (with a liquid-nitrogen cold trap) backed by a mechanical fore pump. Ionization gages are located upstream from the test section and downstream from the pump to monitor system vacuum.

The entire facility is mounted on a movable bridge which can be positioned in the back pool or moved to the front face of the reactor core. The pumping unit is mounted in a framework which allows both vertical and sidewise movement of the system to facilitate the insertion and removal of specimen assemblies and the maneuvering required to insert the test section in the core position.

The specimen subassembly is inserted through the upper side of the tee section. The assembly header is the point of exit of thermocouple and measurement leads through hermetic seals. The specimen assembly is suspended from and fully supported by the header. Two large elastomer 0-rings were used to form the closures on each side of the water-exposed header flange surfaces.

The specimen lead extensions are brought to an air-conditioned room where the measurement instrumentation is located. Several necessary subsystems are on the movable bridge and include:

(1) Temperature-recording instrumentation with a capacity of 40 thermocouples. 


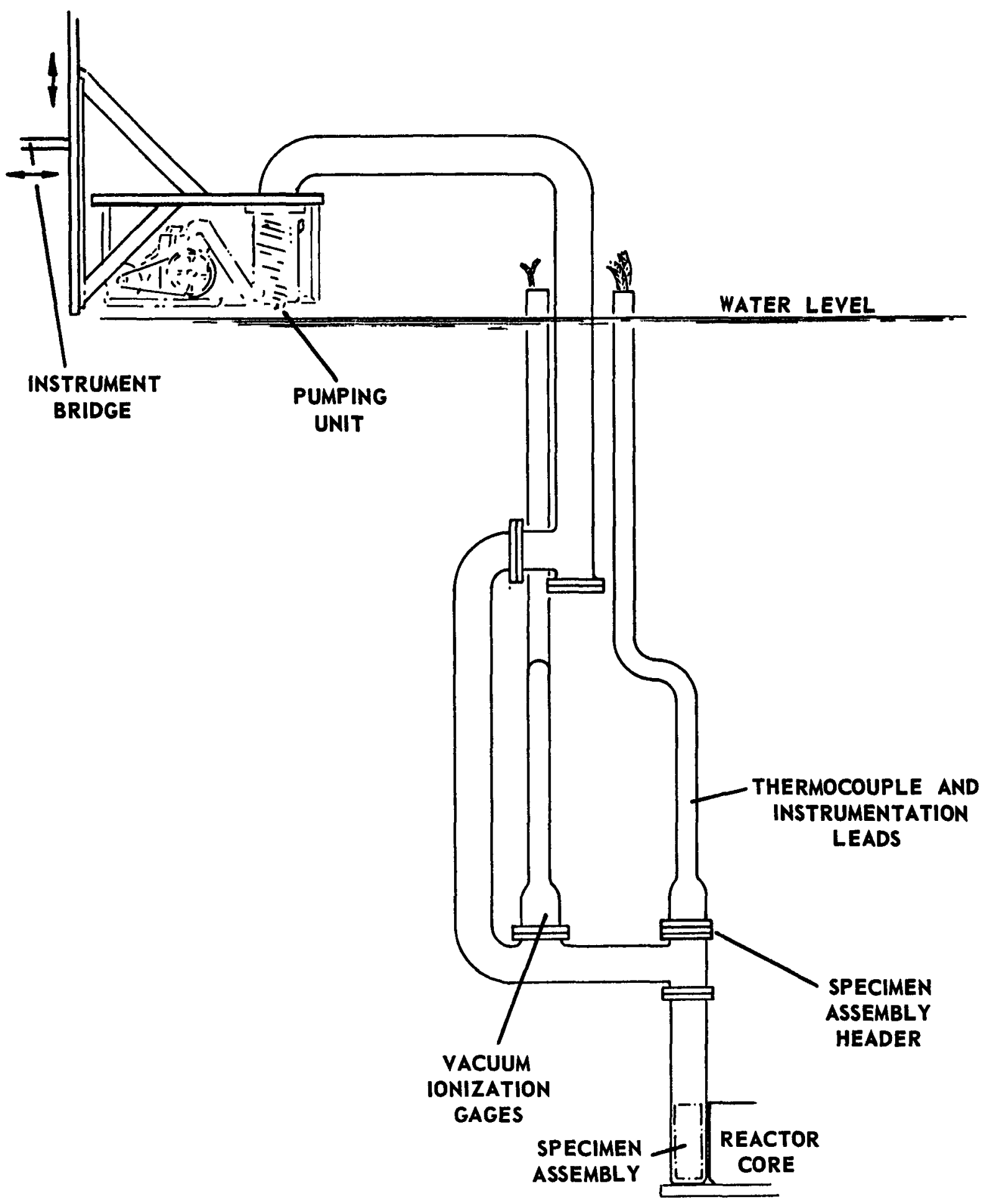

FIGURE 1. VACUUM IRRADIATION FACILITY AT FRONT CORE FACE OF BRR 
(2) Heater control systems for up to six individual 2-kw heaters (manual control).

(3) A circulating water system for specimen cooling.

\section{Specimen Assemblies}

The two experiments described in this report were alike with respect to general design practice, auxiliary heating, thermocoupling, etc. The following design aspects were basic to each:

(1) Bare wire Chromel-Alumel thermocouples were spot welded on the specimens at selected locations for in-pile temperature monitoring, with the exceptions noted in the experiment design descriptions. Between the specimen zone and the top seal plate, the thermocouple wires were insulated with 60 per cent $\mathrm{Al}_{2} \mathrm{O}_{3}$ protection tubing. Mechanical connections were made between the wires and the glasssealed lead-out pins.

(2) All specimen monitoring leads were bare 0.045-in. diameter nickel wire insulated with ceramic tubing. In most cases the connections were made in or near the specimen zones. Several cable samples extended to the top of the test chamber and were connected to the lead-outs with short lengths of wire.

(3) Each experiment assembly included several independently controlled 1/8-in. -OD stainless steel-sheathed auxiliary heaters. The heaters were interposed between either individual specimens or specimen zones and the water-contacting test chamber. The heaters were used during neutron exposure to regulate specimen temperatures by functioning, essentially, as variable-temperature thermal-radiation baffles. The heaters were also employed to maintain specimens at temperature during scheduled reactor-shutdown periods and to heat the specimens to temperature to obtain preirradiation base-line performance data. All gamma and electrical heat was transferred to the chamber wall except as noted below.

(4) The experiment assemblies were suspended on three 1/4-in. rods attached to the top seal plate. The seal plate contained 19 lead-out sites. Measurement and thermocouple leads emerged from the vacuum chamber through 9-pin hermetic seals. These seals were held in place by an $\mathrm{O}$-ring and threaded brass bushing. The heater leads and water lines were brazed into metal plugs; the plugs were sealed in the header using the $\mathrm{O}-\mathrm{ring}$ and bushing arrangement.

(5) Specimen locations were dictated by irradiation-exposure specifications and by heat-transfer considerations. 
$\underline{\text { HF-6 Assembly }}$

The HF-6 experiment is shown in various stages of assembly in Figure 2. The specimens included in this experiment were:

(1) Two 12-lead cable harnesses each consisting of 4 connectors (19 pin, 6 pin, 4 pin, and 2 pin) with appropriate glass-fiber insulated connecting cable

(2) Two limit switches (one actuated)

(3) Two connectors (one 2 pin, D-119, one 4 pin, D-133)

(4) Six 6-ft metallic sheath cable samples (5 in as-received condition, I baked out prior to installation).

The specified operating temperature for all specimens was $700 \mathrm{~F}$. The specimens were mounted in three separately heated zones. Most of the connecting cables and cable samples were strapped to the inner walls of the rectangular baffle boxes which formed the top and bottom zones to achieve uniform temperatures. The other samples were mounted in the open middle zone, except the massive 19-pin connectors. Heat-transfer calculations indicated that the large connector could not be located with the less massive specimens and operate at the same temperature. Calculations also confirmed that the large connector would operate in excess of $700 \mathrm{~F}$ if it were completely enclosed in the bottom baffle box. Therefore, it was mounted in conforming slots in the baffle. The 6-ft cable samples were extended from the lower end of the bottom baffle box to the top of the test chamber and consequently passed through all three zones.

Thermocouples could not be attached directly to the glass-fiber insulated cables. -Cable-bundle temperatures were monitored by inserting the thermocouple bead in the center of the bundle. Where the cables were strapped to the baffle surface, the thermocouples were spot welded to the baffle surface adjacent to the cables.

$\underline{H F-7 \text { As sembly }}$

The HF-7 specimen assembly is shown in Figure 3. The following components were included:

(1) Two resistance temperature detectors (RTD)

(2) Two electrically actuated band release devices (EABRD)

(3) Nine deposited-film resistors mounted on ceramic boards

(4) Two limit switches (one actuated)

(5) One actuated push-button switch.

The specified operating temperature for the platinum temperature-sensing element in each RTD was $1010 \mathrm{~F} \pm 10 \mathrm{~F}$. Each element was surrounded by a zinc heat-sink bath contained in a graphite crucible. The crucible was sealed in a 3-1/2-in. -OD x 7-in. long stainless steel can. Six sheathed thermocouples were inserted in holes in the 

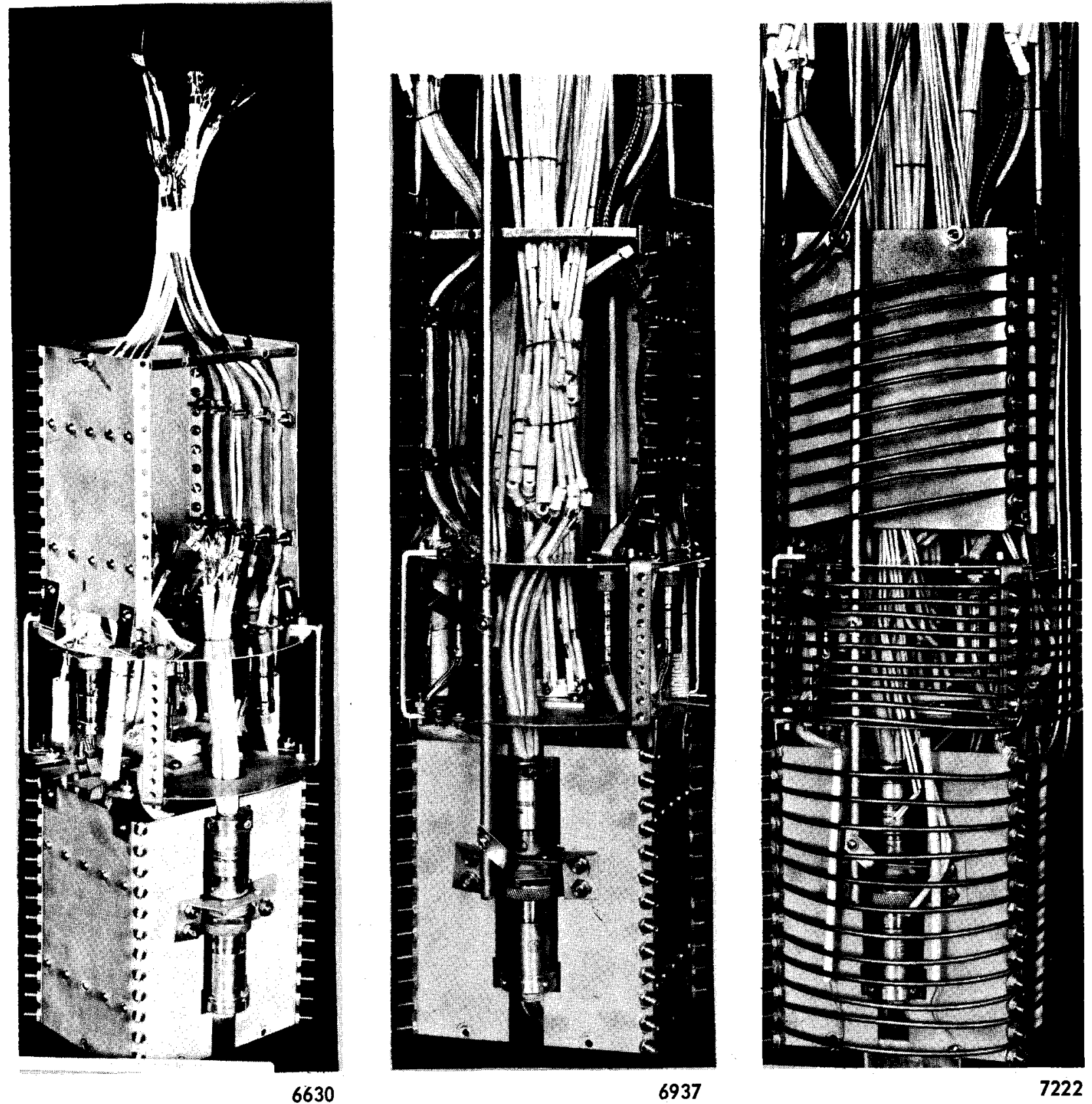

FIGURE 2. EXPERIMENT HF-6 IN VARIOUS STAGES OF ASSEMBLY 

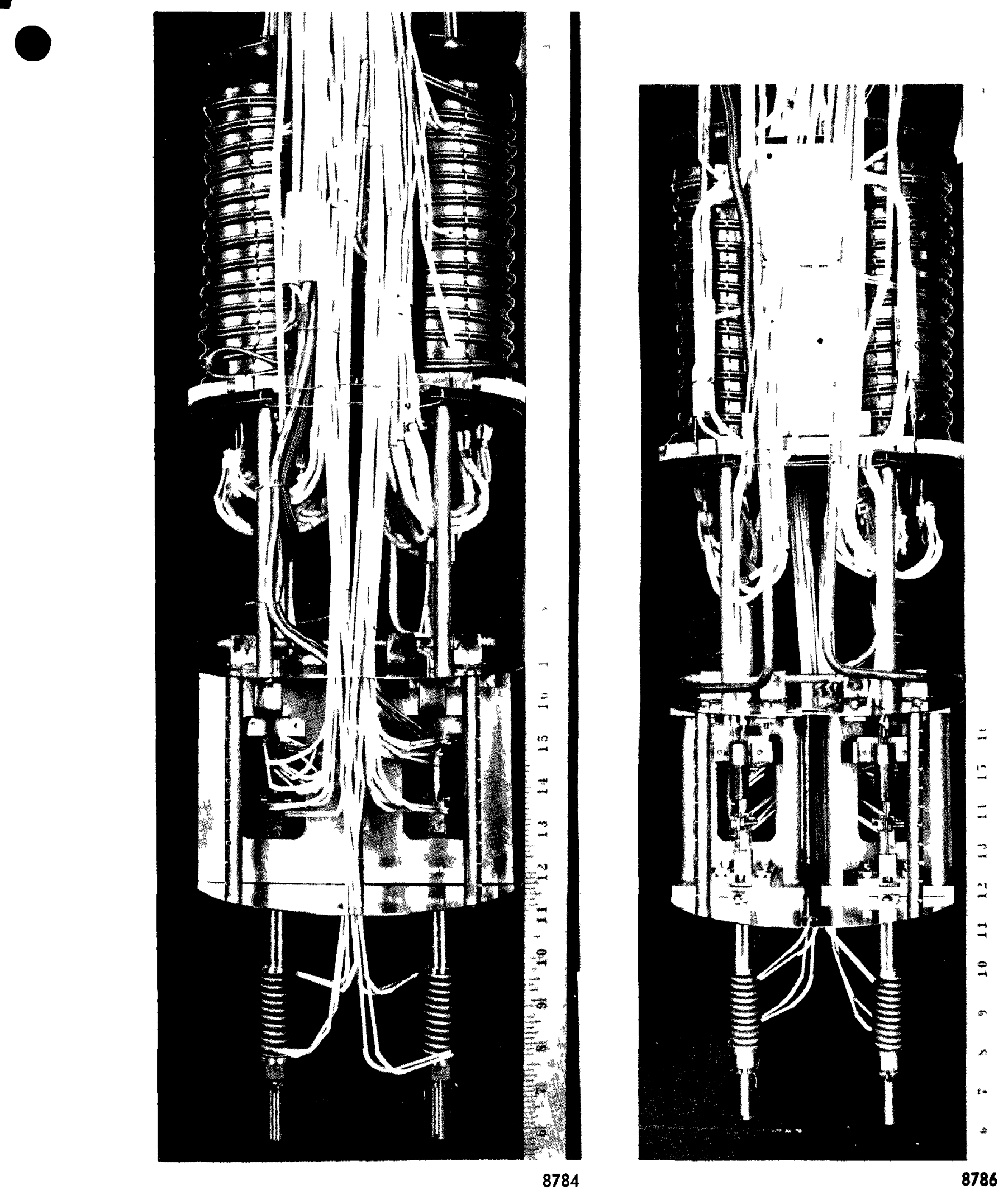

FIGURE 3. SPECIMEN ASSEMBLY FOR EXPERIMENT HF-7 
graphite wall with their beads positioned at several locations along the axial length of the element. The sheaths were welded to the bottom of the container at the point of exit, as was the connector on which the element was mounted. These fixtures were positioned side by side in the test chamber with the axial center of the platinum elements located 21 in. above the bottom of the chamber. A sheathed heater was wrapped on the outside diameter of each fixture for temperature control. The mating half on the connector for the sensor element leads was attached to a sheathed cable which extended to the vacuum seal at the top of the test chamber. The sheathed thermocouple pairs were spot welded to bare Chromel and Alumel lead-outs.

The resistors and switches were to operate at 700 to $900 \mathrm{~F}$ without controlled auxiliary electrical heat. The masses of these components were small and calculations showed that gamma heating alone would not be sufficient to raise their temperature above $500 \mathrm{~F}$. Therefore, they were interposed between the RTD's and the chamber wall to absorb and reradiate the thermal radiation from the RTD's.

The specified operating temperature for the gold-plated separable EABRD links was $500 \mathrm{~F}$. The links were mounted in massive fixtures and the fixtures were located in the highest gamma flux available in the test chamber. The temperature of the link was dependent on its emissivity, the temperature of the loading clevises and case, and the contact conductances from the link to the case. Calculations indicated that the link temperature could be held under $500 \mathrm{~F}$ if the case temperature was reduced substantially and if the as sumption of high contact conductances from the link to the clevis, and from the clevis to the case, was valid. Cooling lugs were welded to the fixture cases and a water-cooling coil was brazed to the lugs. The lug size was adequate to cool the case but restrictive enough to prevent the loss of additional heat when heaters were employed to control the link temperature at $500 \mathrm{~F}$.

\section{FLUX-LEVEL CONSIDERATIONS AND MEASUREMENTS}

\section{Background}

The nuclear environments attained in Experiments $\mathrm{HF}-6$ and $\mathrm{HF}-7$ were determined.by the following factors:

(1) The specifications of neutron and gamma-ray exposures for the specimens, as presented in Table 1

(2) The use of a BRR irradiation facility large enough to house the 8 -in. test chamber and its associated shielding

(3) An irradiation period for each experiment of three normal BRR operating cycles (total irradiation time $864 \mathrm{hr}$ ).

Initial examination of the specified exposures indicated the need for adjustment of the thermal-neutron fluxes and gamma exposure rates available in the irradiation site chosen to meet the requested fast neutron fluxes. A 3/8-in. -thick aluminized lead shield was interposed between the reactor core and test section to reduce the gamma exposure rate; a $0.007-$ in. -thick cadmium shield containing two vertical slots was 
placed around the test section to depress the thermal-neutron flux. The center line of the cylindrical test chamber was 5.1 in. from the core face for maximum fast-neutron flux, as illustrated in Figure 4.

TABLE 1. NUCLEAR ENVIRONMENTS SPECIFIED FOR EXPERIMENTS HF-6 AND HF-7

\begin{tabular}{|c|c|c|c|c|}
\hline \multirow[b]{2}{*}{ Experiment } & \multirow[b]{2}{*}{ Component } & \multicolumn{2}{|c|}{ Neutron Flux, $\mathrm{n} / \mathrm{cm}^{2}$} & \multirow[b]{2}{*}{ Gamma, $\mathrm{R}$} \\
\hline & & Fast & Thermal & \\
\hline $\mathrm{HF}-6$ & All & $1.5 \times 10^{19}$ & $1.8 \times 10^{18}$ & $1.5 \times 10^{10}$ \\
\hline $\mathrm{HF}-7$ & EABRD & $1.5 \times 10^{19}$ & $1.8 \times 10^{18}$ & $1.5 \times 10^{10}$ \\
\hline $\mathrm{HF}-7$ & RTD & $5.0 \times 10^{18}$ & $6.0 \times 10^{17}$ & $1.0 \times 10^{10}$ \\
\hline
\end{tabular}

Flux-level investigations included measurements performed both in a mock-up of the test section, and in the test-specimen assembly during irradiation. Both neutron and gamma exposures were considered.

\section{Mock-up Measurement Techniques and Data}

Preliminary mock-up data were used in arriving at the final design of the test section and its shielding, after which detailed measurements added information on neutron spectra and the distributions of neutron fluxes and gamma exposure rates throughout the volume to be occupied by the test specimens.

The mock-up chamber was fabricated from a 40-in. section of 8-in.-diameter Schedule 40 aluminum pipe. A 1/4-in. -thick plate was welded to the bottom, and the top was fitted with a removable cap attached to a lead tube. Dosimeters were supported by special holders inserted in the chamber. Mock-up operations were conducted at reactor power levels varying from $200 \mathrm{kw}$ to $1 \mathrm{Mw}$, depending on the activation characteristics of the detectors. Extrapolation to full reactor power of $2 \mathrm{Mw}$ was based on information taken from several power monitors.

The incident neutron field was divided into three energy groups (fast, resonance, and thermal) and investigated by techniques applicable to each of these groups.

Fast neutrons are defined as those with energies greater than $0.1 \mathrm{Mev}$, resonance neutrons are those ranging in energy from $0.1 \mathrm{Mev}$ to $0.4 \mathrm{ev}$, while thermal neutrons include those of energies below $0.4 \mathrm{ev}$.

Neutron measurements consisted of energy-spectrum determinations for the fast and resonance groups, as well as the flux distributions throughout the volume of the test section for fast, resonance, and thermal neutrons. (Fast- and resonance-spectra and resonance-distribution measurements were made prior to Experiments $\mathrm{HF}-6$ and HF-7. The methods used for these measurements are detailed in Report BMI-X-310 covering Experiments HF-1 through $\mathrm{HF}-4$.) 


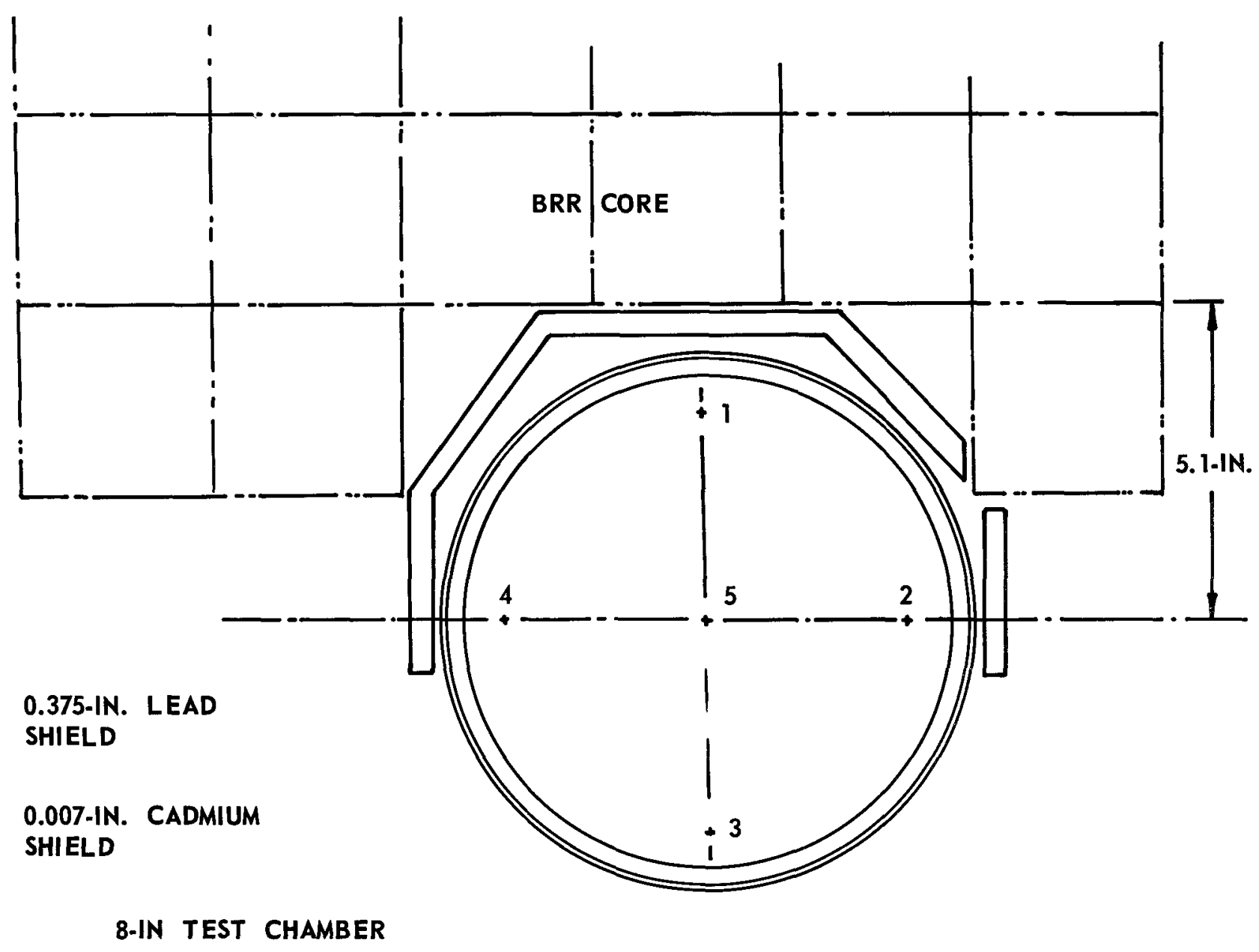

FIGURE 4. THE POSITION OF THE HIGH-FLUX EXPERIMENT SPECIMEN CHAMBER RELATIVE TO THE BRR CORE 
Neutron Spectra

Representations of the fast-neutron spectrum were obtained at two elevations in the mock-up chamber from the integral neutron fluxes measured by six detectors whose reaction cross-section values approximate step increases at threshold energies ranging from $0.1 \mathrm{Mev}$ to several Mev. The data, fitted to the integral Watts fission spectrum, were normalized to an integral fast neutron flux of one at $0.1 \mathrm{Mev}$ as shown in Figure 5.

The resonance neutron spectrum was obtained from the differential neutron fluxes measured by four resonance detectors in combination with the cadmium-difference method of analysis, which may be used only if the differential neutron flux is proportional to the reciprocal neutron energy. Analysis of the detector data confirmed this inverse proportionality over the measured energy range.

The resultant differential spectrum, normalized to unit flux at $0.1 \mathrm{kev}$, is shown in Figure 6. This spectrum is represented mathematically as

$$
\phi(E)=\phi_{0} / E
$$

where $\phi_{0}$ is a spectral function parameter.

\section{Neutron-Flux Distribution}

The fast, thermal, and resonance neutron flux distributions were determined by measurements at five radial positions in the test chamber, as shown in Figure 4, and over a 33-inch axial span in the chamber.

The fast-neutron distribution was measured by nickel wire dosimeters. The resultant threshold flux values were corrected to total fast-neutron fluxes (i. e., energies above $0.1 \mathrm{Mev}$ ) by use of the established fast-neutron spectrum. The volumeaveraged fast-neutron flux from 1 to 25 in. above the chamber bottom was $2.1 \times 10^{12}$ $\mathrm{n} /\left(\mathrm{cm}^{2}\right)(\mathrm{sec})$.

The thermal-neutron distribution was measured by cobalt wire dosimeters exposed bare and enclosed in 0.020 to 0.040 -in. -thick cadmium covers. Differences in the responses of the bare and cadmium-covered detectors are proportional to the thermalneutron flux. The volume-averaged thermal-neutron flux from 2 to $30 \mathrm{in}$. above the chamber bottom was $5.3 \times 10^{11} \mathrm{n} /\left(\mathrm{cm}^{2}\right)(\mathrm{sec})$.

The resonance-neutron distribution was determined by the cadmium-difference method applied to cobalt wire detectors exposed bare and enclosed in 0.020 to 0.040-in. thick cadmium, as detailed in Report BMI-X-310. Values of the resonance spectral function parameter $\left(\phi_{O}\right)$ were actually tabulated, permitting the determination of the total neutron flux in any subgroup within the resonance-neutron energy range by integration of the differential spectrum, Equation (1), between the chosen limits of energy. The volume-averaged value of $\phi_{0}$ from 1 to 19 in. above the chamber bottom was $2.9 \mathrm{x}$ $10^{11} \mathrm{n} /\left(\mathrm{cm}^{2}\right)(\mathrm{sec})$, yielding an average total resonance-neutron flux of $3.6 \times 10^{12}$ $\mathrm{n} /\left(\mathrm{cm}^{2}\right)(\mathrm{sec})$.

For each set of neutron-distribution measurements, the flux values at the five radial positions were averaged at various axial positions. Figure 7 indicates these average radial fluxes as functions of axial position. 


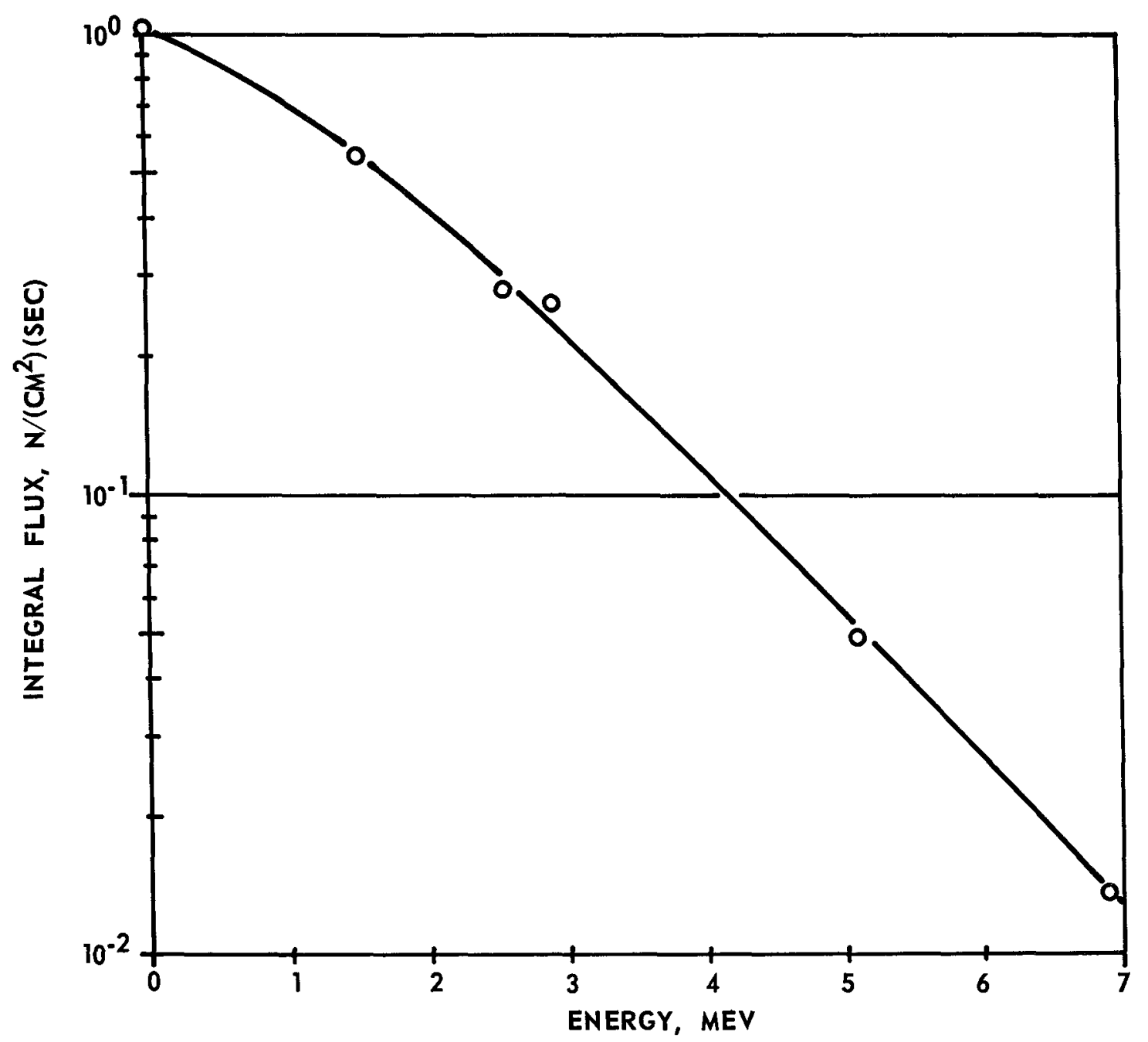

FIGURE 5. FAST-NEUTRON-FLUX SPECTRUM 


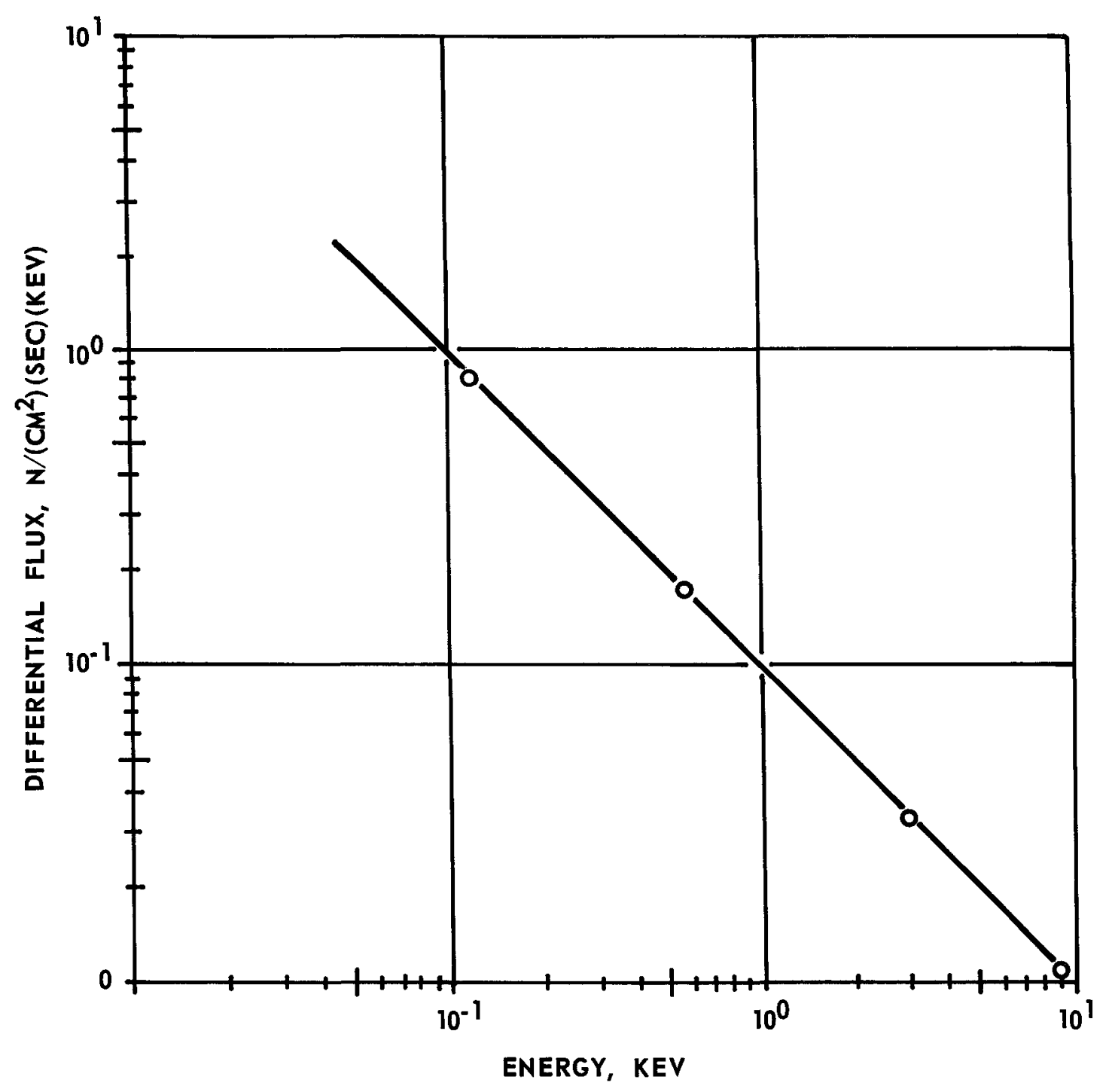

FIGURE 6. RESONANCE-NEUTRON-FLUX SPECTRUM 


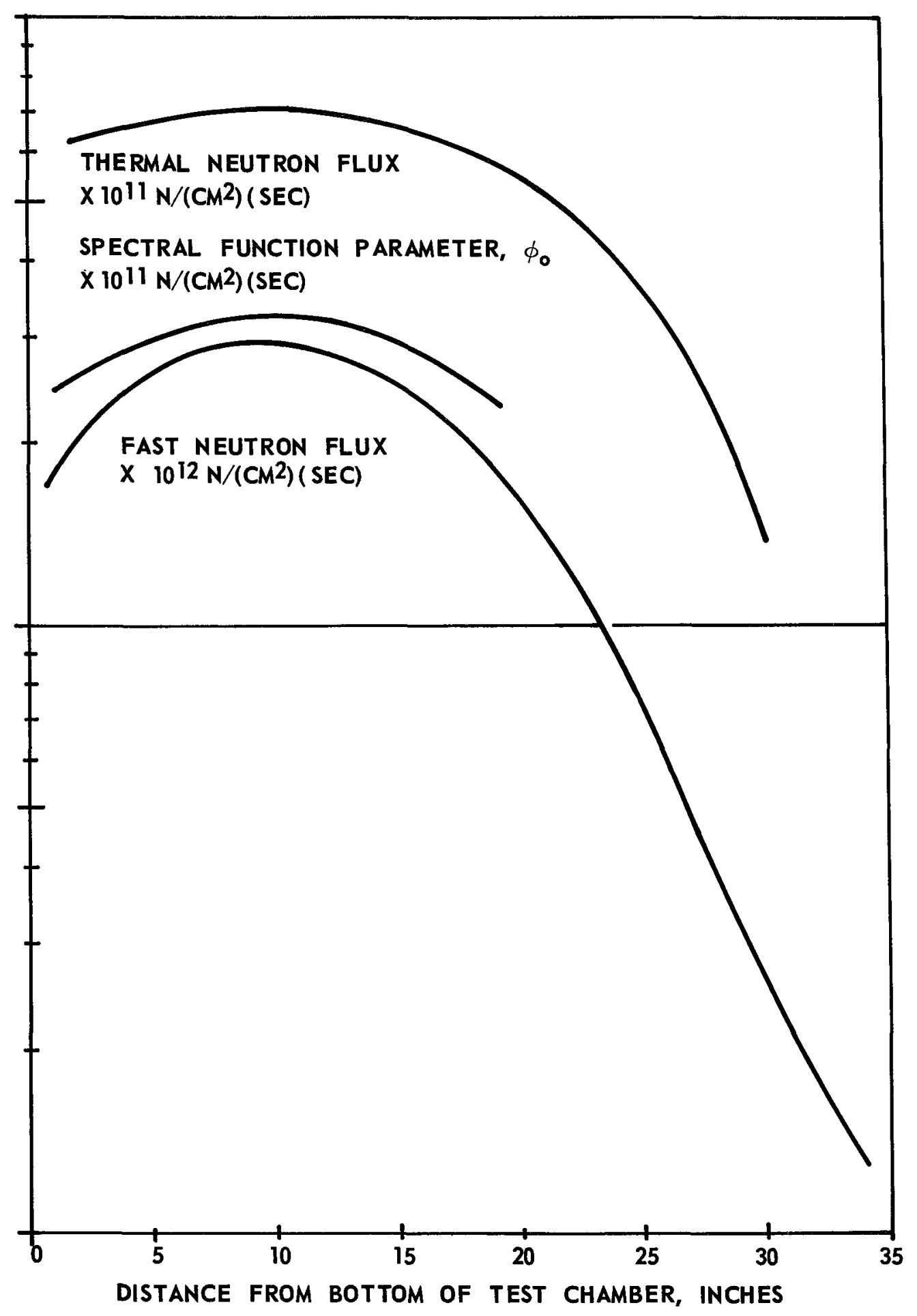

FIGURE 7. NEUTRON-FLUX DISTRIBUTIONS IN MOCK-UP 
Gamma-Exposure-Rate Distribution

Gamma-exposure-rate measurements were made in the mock-up chamber at the same five radial positions as for the neutron distributions (see Figure 4) and over a 28inch axial span. Measurements were made with $10-\mathrm{cm}^{3}$ graphite-walled ionization chambers through which was maintained a small flow of carbon dioxide at atmospheric pressure. A regulated power supply applied $500 \mathrm{v}$ to the chambers, and the current outputs were measured by a Keithley Model 610A Electrometer.

The ionization chambers were calibrated at the Battelle Cobalt-60 Irradiation Laboratory using copper-modified ferrous sulfate chemical dosimeters. Gamma measurements were corrected for the presence of fast neutrons, this correction being $9.3 \times 10^{-5} \mathrm{erg} /(\mathrm{g})(\mathrm{hr})(\mathrm{carbon})$ per $\mathrm{n} /\left(\mathrm{cm}^{2}\right)(\mathrm{sec})$. The volume-averaged exposure rate from 1 to $29 \mathrm{in}$. above the chamber bottom was $2.2 \times 10^{7} \mathrm{R} / \mathrm{hr}$. Figure 8 shows the average radial exposure rate as a function of axial position in the mock-up chamber.

\section{IN-PILE OPERATION}

\section{Experiment HF-6}

\section{Operation}

This experiment was irradiated for $802 \mathrm{hr}(93$ per cent of the specified irradiation period) during BRR Cycles 149 and 150, and during parts of Cycles 151 and 152 . The experiment remained out-of-pile for 9 days after the end of Cycle 150 to obtain out-ofpile specimen performance data. Most of the irradiation time which was lost during this 9-day period was regained in Cycle 152.

\section{Temperature Levels}

Specimen temperatures are summarized in Table 2. The cable harness designated 106 was installed closer to the reactor core than cable harness designated 100 . Temperatures measured in the former were 25 to $50 \mathrm{~F}$ higher than those monitored at similar locations on the latter. Temperatures were maintained at constant elevated levels throughout this experiment; temperature distributions were altered during scheduled reactor shutdowns. Occasional temperature variations caused by reactor power changes were subsequently corrected by heater adjustments.

During the out-of-pile period following the second cycle, temperatures were maintained at nominal operating values for 4 days. The top-zone temperature was then raised to $800 \mathrm{~F}$ for 5 days to observe the effects of temperature change on specimen performance. When the experiment was repositioned in-pile, temperatures were restored to normal levels.

On the second day of the last cycle, the temperature of the top zone was again in$c r e a s e d$ to $800 \mathrm{~F}$ for the remainder of the irradiation (4 days). This increase caused a 10 to $15 \mathrm{~F}$ temperature rise in the uncabled connectors and in the limit switches in the middle zone. 


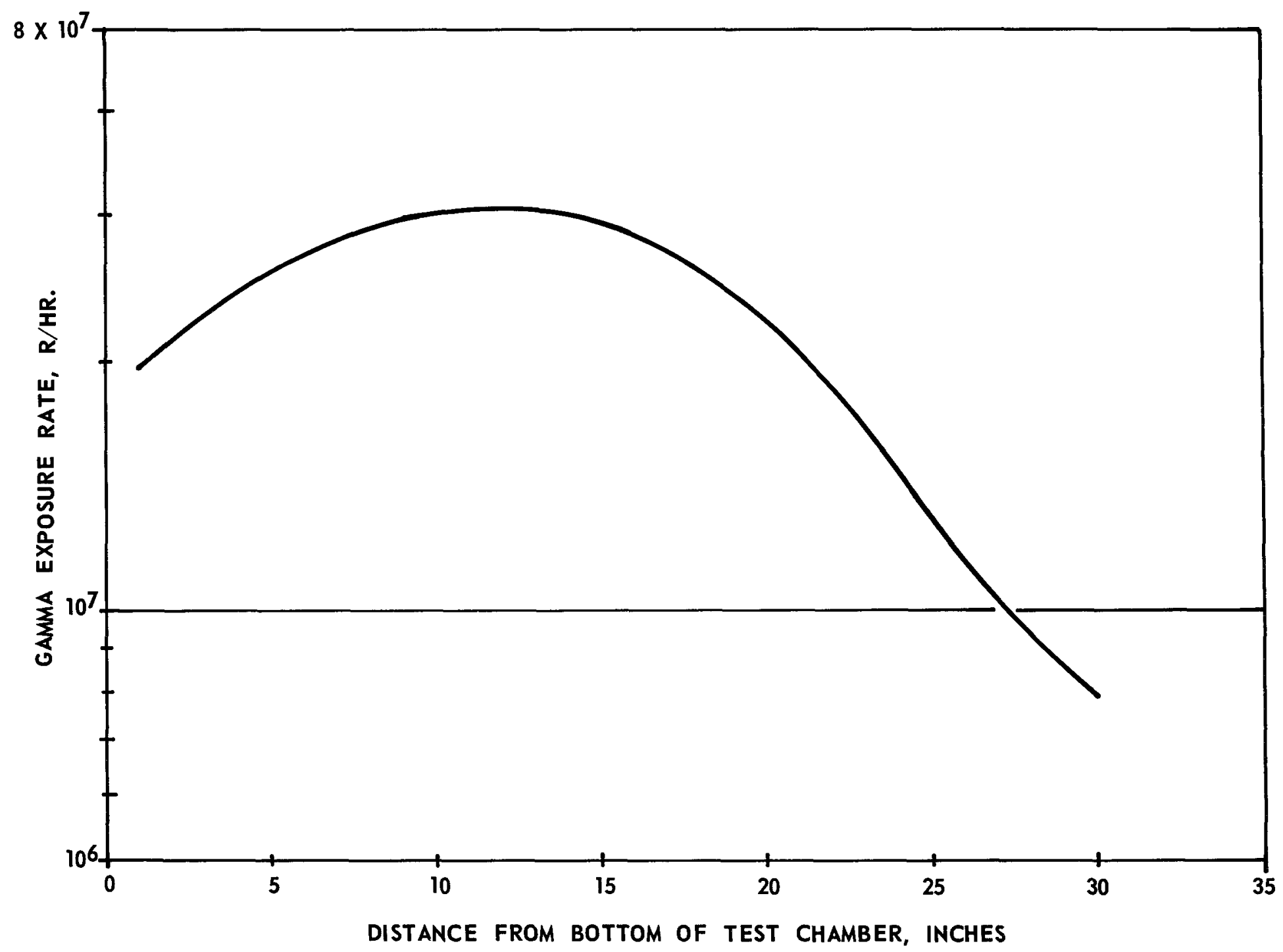

FIGURE 8. GAMMA-EXPOSURE-RATE DISTRIBUTION IN MOCK-UP 
TABLE 2. SUMMARY OF SPECIMEN TEMPERATURES IN EXPERIMENT HF-6

\begin{tabular}{|c|c|c|c|c|c|}
\hline \multirow{2}{*}{ Sample } & \multirow[b]{2}{*}{ Zone } & \multicolumn{4}{|c|}{ Average Temperature, $F$, and Limits } \\
\hline & & Cycle 149 & Cycle 150 & Cycle 151 & Cycle 152 \\
\hline \multicolumn{6}{|l|}{ Cable Harness 100} \\
\hline 19-pin connector, upper half & 3 & $740 \pm 10$ & $745 \pm 5$ & $750 \pm 10$ & $740 \pm 15$ \\
\hline 19-pin connector, lower half & 3 & $700 \pm 10$ & $710 \pm 10$ & $720 \pm 10$ & $710 \pm 15$ \\
\hline Cables & 3 & $660 \pm 10$ & $660 \pm 10$ & $660 \pm 10$ & $650 \pm 15$ \\
\hline 6-pin connector & 2 & $725 \pm 10$ & $725 \pm 10$ & $730 \pm 5$ & $725 \pm 20$ \\
\hline 6-pin connector sheath & 2 & $685 \pm 10$ & $680 \pm 20$ & $680 \pm 5$ & $680 \pm 20$ \\
\hline 4-pin connector & 2 & $720 \pm 20$ & $735 \pm 5$ & $740 \pm 5$ & $730 \pm 15$ \\
\hline 4-pin connector sheath & 2 & $680 \pm 10$ & $680 \pm 5$ & $680 \pm 5$ & $675 \pm 15$ \\
\hline Single conductor lug & 2 & $660 \pm 10$ & $660 \pm 10$ & $665 \pm 5$ & $660 \pm 20$ \\
\hline Cables & 1 & $710 \pm 10$ & $710 \pm 10$ & $715 \pm 5$ & $810 \pm 15(c)$ \\
\hline \multicolumn{6}{|l|}{ Cable Harness 106} \\
\hline 19-pin connector, upper half & 3 & $765 \pm 5$ & $765 \pm 15$ & $775 \pm 10$ & $775 \pm 20^{(d)}$ \\
\hline 19-pin connector, lower half & 3 & $750 \pm 30$ & $745 \pm 25$ & $760 \pm 10$ & $750 \pm 15$ \\
\hline Cables & 3 & $685 \pm 10$ & $685 \pm 5$ & $685 \pm 10$ & $675 \pm 15$ \\
\hline 6-pin connector & 2 & $760 \pm 20$ & $765 \pm 10$ & $770 \pm 10$ & $755 \pm 15$ \\
\hline 6-pin connector sheath & 2 & $705 \pm 15$ & $700 \pm 10$ & $700 \pm 10$ & $690 \pm 20$ \\
\hline 4-pin connector (a) & 2 & -- & -- & -- & -- \\
\hline 4-pin connector sheath & 2 & $705 \pm 20$ & $700 \pm 10$ & $695 \pm 5$ & $700 \pm 25$ \\
\hline Single conductor lug & 2 & $685 \pm 15$ & $675 \pm 10$ & $670 \pm 10$ & $670 \pm 20$ \\
\hline Cable & 1 & $745 \pm 5$ & $745 \pm 10$ & $750 \pm 5$ & $800 \pm 10^{(c)}$ \\
\hline Limit Switches & 2 & $705 \pm 15$ & $705 \pm 10$ & $705 \pm 10$ & $720 \pm 5$ \\
\hline D-119 Connector & 2 & $735 \pm 10$ & $735 \pm 5$ & $735 \pm 5$ & $740 \pm 5$ \\
\hline D- 133 Connector & 2 & $740 \pm 10$ & $740 \pm 5$ & $740 \pm 5$ & $750 \pm 5$ \\
\hline Cable $U$ and Cable $B(b)$ & 1 & $725 \pm 10$ & $725 \pm 10$ & $725 \pm 5$ & $800 \pm 5(c)$ \\
\hline Top Zone & 1 & $730 \pm 10$ & $730 \pm 10$ & $735 \pm 5$ & $800 \pm 5(c)$ \\
\hline Bottom Zone & 3 & $670 \pm 10$ & $670 \pm 10$ & $660 \pm 10$ & $660 \pm 20$ \\
\hline
\end{tabular}

(a) This thermocouple was open before the start of the irradiation.

(b) These cables as well as Cable Samples 1, 2, 3, and 4 passed through all the zones. However, the temperatures of sheaths of Cables $U$ and $B$ were monitored in the top zone.

(c) This is the average temperature after the temperature was increased on the second day of the cycle.

(d) Estimated, Recording instrument out of calibration during this period. 
Vacuum Levels

The vacuum readings monitored in Experiment $\mathrm{HF}-6$ are presented in Figure 9. After the first week of operation, the vacuum level in the test section was $2 \times 10^{-5}$ torr; it remained below $1 \times 10^{-5}$ torr during the last 4 weeks of the irradiation.

The ionization-gage filaments remained in continuous operation throughout this experiment. One of the ion gages located at the test section failed near the end of the third cycle and the alternate gage was used until the completion of the experiment.

\section{Electrical Measurements}

This section presents the methods employed to obtain performance data and a summary of the performed measurements. A limited amount of data is presented in the report, but these data were only recorded as part of normal experiment surveillance. The data are not evaluated and cannot be assumed to be a true indication of the component performance under actual operating conditions.

The measurement equipment was located in a temperature- and humiditycontrolled room one floor below the reactor pool surface. TV-type multiconductor cables connected the capsule lead-outs to a pool-side terminal box. The cabling between this box and the instrument room had been permanently installed for earlier experiments.

All of the specimen leads were terminated in the instrument room in a crossbar scanner connected as a 6-level, 100-point switch. The six outputs of the crossbar scanner were connected to the measurement control chassis. A mode selector switch was used to select the proper scanner level outputs for either two-wire measurements (insulation resistance and higher resistance measurements) or four-wire measurements (low resistances and contact resistances where the lead resistance would introduce error).

Insulation-resistance measurements were made with the circuit shown in the lower part of Figure 10. Switch $S_{1}$ was adjusted to produce at least three significant figures on the digital voltmeter. With Switch $S_{2}$ in the "a" position, the power supply was adjusted until the voltage drop across the shunt resistor was $50.00 \mathrm{v}$. With Switch $S_{2}$ in the "b" position, Switch $\mathrm{S}_{3}$ was closed. After a specified time interval, the digital voltmeter was placed in the hold mode, and Switch $\mathrm{S}_{3}$ was opened. The insulation resis tance of the specimen could then be computed from the DVM reading as follows:

$$
\mathrm{IR}=\frac{50.00}{(\mathrm{DVM}) / \mathrm{R}_{\mathrm{sh}}}
$$

The resistance and contact-resistance measurements were made with the circuit shown in the upper part of Figure 10. The value of resistance was computed as follows:

$$
R=\frac{(D V M \text { No. } 1)}{(D V M \text { No. } 2) / R_{\text {sh }}}
$$

The value of $R_{\text {Sh }}$ was $1 \mathrm{ohm}$, and thus the resistance was the ratio of the two DVM readings. 


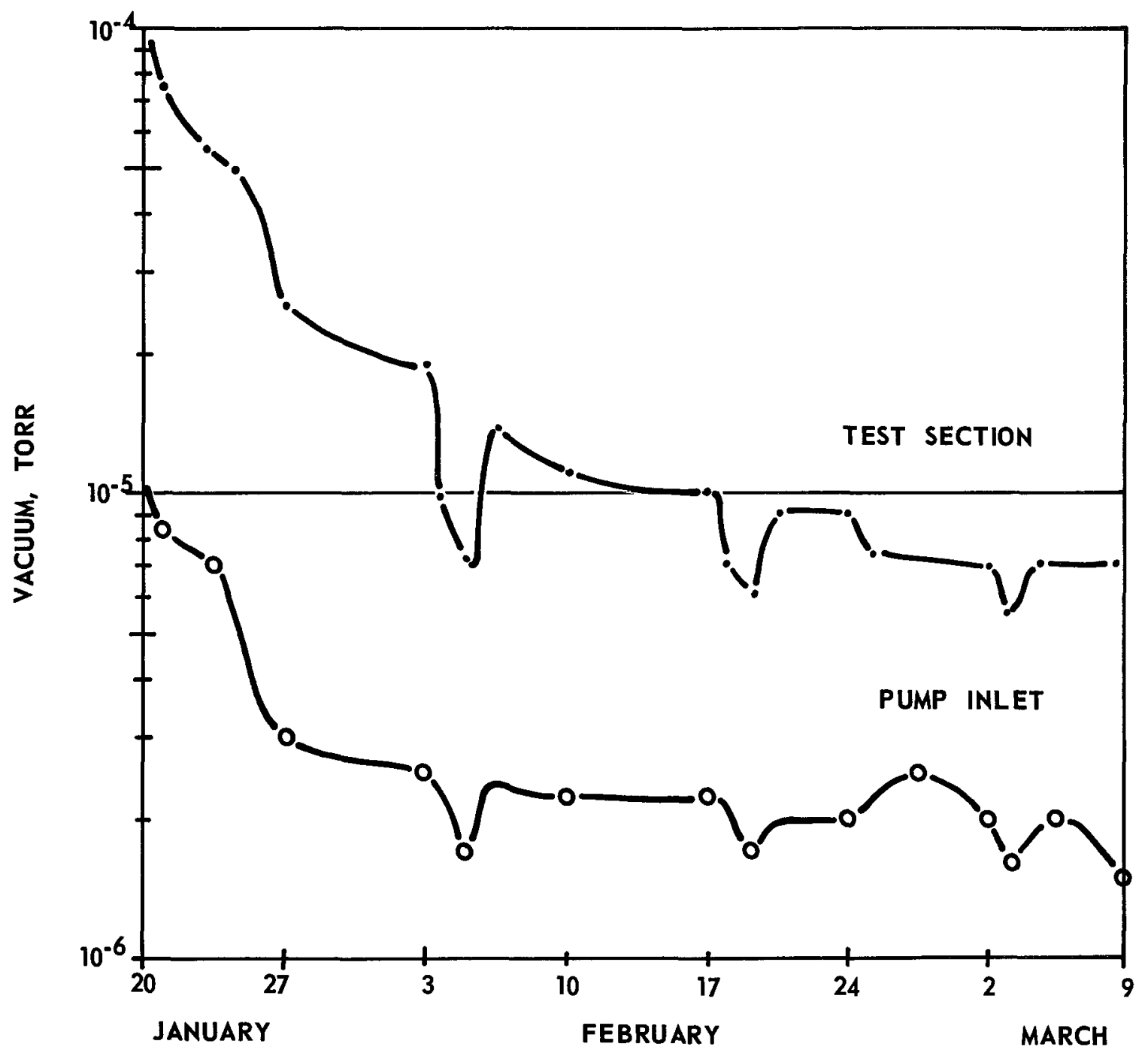

FIGURE 9. VACUUM LEVELS MONITORED IN THE HF-6 EXPERIMENT 


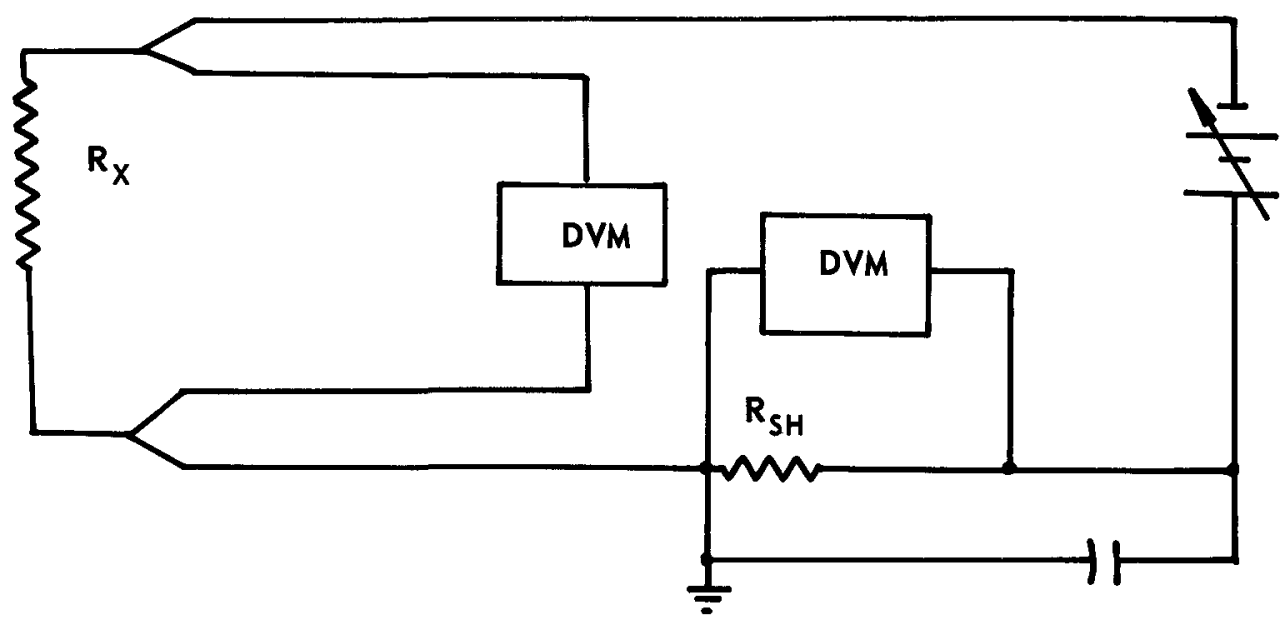

RESISTANCE AND CONTACT RESISTANCE MEASUREMENT CIRCUIT

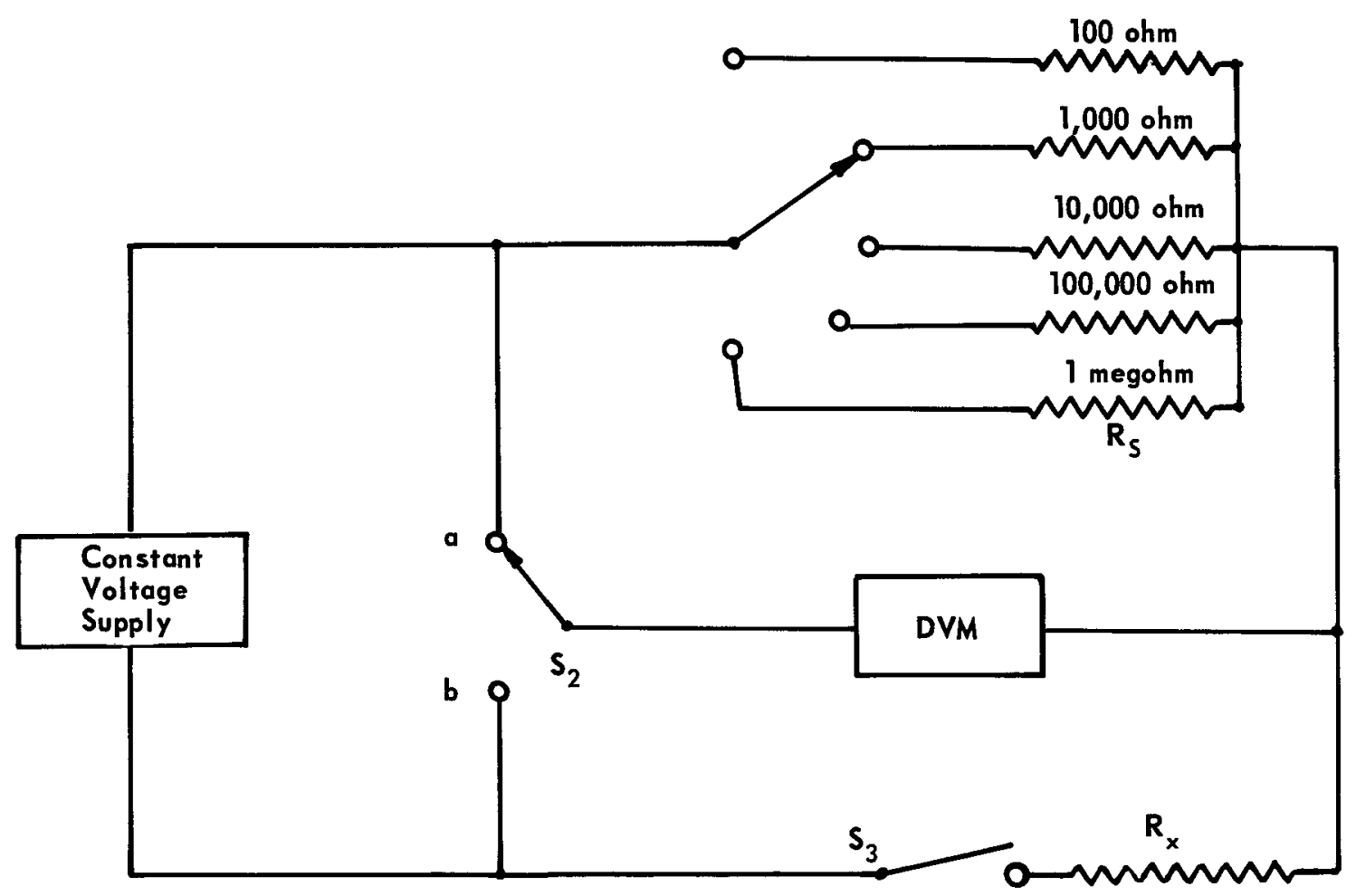

INSULATION RESISTANCE MEASURING CIRCUIT

PROVIDED BY ATOMICS INTERNATIONAL

FIGURE 10. BASIC MEASURING CIRCUITS EMPLOYED IN EXPERIMENTS HF-6 AND HF-7 
All data were recorded directly on punch cards using an IBM 526 summary punch and the punch-control circuitry from the automatic data system developed for the LF-1 experiment (described in BMI-X-290). The punch cards were sorted every week to arrange the data for each specimen in chronological order. The cards were forwarded to Atomics International for data analysis.

The specimen performance measurements are identified by scanner point numbers as shown in Table 3. The notations P1, P2, etc., refer to specified wires in the cable harnesses. The internal test refers to a pair of dummy leads extending down into the specimen region of the capsule. The external test leads terminated at the feedthroughs in the capsule header plate.

Measurements were made prior to the irradiation to obtain base-line data. After the first day of irradiation, when six sets of data were taken, measurements were taken two times a day, 7 days a week for the remainder of the experiment.

Data from selected scanner points are presented in Figures 11 through 17. The scanner points are identified in the figures. The darkened areas along the bottom of the figures indicate the periods at full reactor power.

\section{Experiment $\mathrm{HF}-7$}

Operation

The HF-7 experiment was irradiated for $820 \mathrm{hr}$ during BRR Cycles 153, 154, and 155 (95 per cent of specified irradiation period).

Temperature Levels

Selected specimen temperatures are plotted in Figures 18 and 19 and are summarized in Table 4. The RTD element temperatures as monitored by the internal thermocouples were maintained at $1010 \mathrm{~F} \pm 15 \mathrm{~F}$ throughout the irradiation except as noted in later sections. The internal Chromel-Alumel thermocouples were monitored with a high-precision potentiometer using a compensating distilled-water ice bath. In RTD 119, the six internal thermocouples were usually all within a 6 to 8 -degree spread. The thermocouples in RTD 107 were as consistent until the element circuit failed within the device on the fifth day of the second cycle. The internal-thermocouple temperature spread gradually increased from 12 to $30 \mathrm{~F}$. During the course of irradiation, it was necessary to increase the auxiliary heat to RTD 107 frequently to maintain its temperature at $1010 \mathrm{~F}$; at the same time, the heat addition to the other RTD was being reduced frequently to control specimen temperature.

During the initial reactor cycle start-up, it was evident that the EABRD link temperatures would exceed the desired $500 \mathrm{~F}$. The experiment was removed from the core position and the core configuration was altered to reduce the gamma flux. The EABRD link temperatures equilibrated at 640 and $675 \mathrm{~F}$, and it was decided to operate at these temperatures. These temperatures fluctuated throughout each cycle and from cycle to cycle as reactor power was adjusted. 
TABLE 3. IDENTIFICATION OF SPECIMEN PERFORMANCE MEASUREMENTS IN EXPERIMENT HF-6

\begin{tabular}{|c|c|c|c|}
\hline $\begin{array}{c}\text { Scanner } \\
\text { Points } \\
\end{array}$ & Specimen & $\begin{array}{l}\text { Insulation } \\
\text { Resistance } \\
\end{array}$ & Resistance \\
\hline 0000 & Cable 100 & Pl to ground & $P_{1}$ to $P 15$ \\
\hline 0001 & Cable 100 & P2 to ground & \\
\hline 0002 & Cable 100 & P3 to ground & P3 to P17 \\
\hline 0003 & Cable 100 & P4 to ground & \\
\hline 0004 & Cable 100 & P5 to ground & P5 to P36 \\
\hline 0005 & Cable 100 & P8 to ground & P8 to P39 \\
\hline 0006 & Cable 100 & P13 to ground & P13 to P32 \\
\hline 0007 & Cable 106 & Pl to ground & $\mathrm{Pl}$ to $\mathrm{P} 15$ \\
\hline 0008 & Cable 106 & P2 to ground & \\
\hline 0009 & Cable 106 & P3 to ground & $\mathrm{P} 3$ to $\mathrm{P} 17$ \\
\hline 0010 & Cable 106 & P4 to ground & \\
\hline 0011 & Cable 106 & P5 to ground & $P 5$ to $P 36$ \\
\hline 0012 & Cable 106 & P8 to ground & $P 8$ to $P 39$ \\
\hline 0013 & Cable 106 & P13 to ground & $\mathrm{P} 13$ to $\mathrm{P} 32$ \\
\hline 0014 & $\begin{array}{l}\text { Actuated } \\
\text { switch }\end{array}$ & $\begin{array}{l}\text { Open contact } \\
\text { to common }\end{array}$ & $\begin{array}{c}\text { Closed contact } \\
\text { to common }\end{array}$ \\
\hline 0015 & $\begin{array}{l}\text { Unactuated } \\
\text { switch }\end{array}$ & $\begin{array}{l}\text { Open contact } \\
\text { to common }\end{array}$ & $\begin{array}{l}\text { Closed contact } \\
\text { to common }\end{array}$ \\
\hline 0016 & Internal test & Lead to lead & Shorted leads \\
\hline 0017 & External test & Lead to ground & Shorted leads \\
\hline 0018 & Cable 100 & $\mathrm{P} 1$ to $\mathrm{P} 2$ & \\
\hline 0019 & Cable 100 & $P 1$ to $P 3$ & \\
\hline 0020 & Cable 100 & $\mathrm{P} 1$ to $\mathrm{P} 4$ & \\
\hline 0021 & Cable 100 & $\mathrm{P} 2$ to $\mathrm{P} 3$ & \\
\hline 0022 & Cable 100 & $\mathrm{P} 2$ to $\mathrm{P} 4$ & \\
\hline 0023 & Cable 100 & $\mathrm{P} 3$ to $\mathrm{P} 4$ & \\
\hline 0024 & Cable 100 & $P 5$ to $P 8$ & \\
\hline 0025 & Cable 106 & $\mathrm{Pl}$ to $\mathrm{P} 2$ & \\
\hline 0026 & Cable 106 & $\mathrm{Pl}$ to $\mathrm{P} 3$ & \\
\hline 0027 & Cable 106 & $\mathrm{Pl}$ to $\mathrm{P} 4$ & \\
\hline 0028 & Cable 106 & $\mathrm{P} 2$ to $\mathrm{P} 3$ & \\
\hline 0029 & Cable 106 & $\mathrm{P} 2$ to $\mathrm{P} 4$ & \\
\hline 0030 & Cable 106 & $\mathrm{P} 3$ to $\mathrm{P} 4$ & \\
\hline 0031 & Cable 106 & $\mathrm{P} 5$ to $\mathrm{P} 8$ & \\
\hline 0032 & Cable B & Lead to ground & \\
\hline 0033 & Cable B & Lead to ground & \\
\hline 0034 & Cable U & Lead to ground & \\
\hline 0035 & Cable U & Lead to ground & \\
\hline 0036 & Connector B & Pin A to ground & \\
\hline 0037 & Connector B & Pin $B$ to ground & \\
\hline 0038 & Connector Y & Pin A to ground & \\
\hline 0039 & Connector $\mathrm{Y}$ & Pin $B$ to ground & \\
\hline 0040 & Cable 1 & Lead to ground & \\
\hline 0041 & Cable 1 & Lead to ground & \\
\hline 0042 & Cable 2 & Lead to ground & \\
\hline
\end{tabular}


TABLE 3. (Continued)

\begin{tabular}{llll}
\hline $\begin{array}{c}\text { Scanner } \\
\text { Points }\end{array}$ & Specimen & $\begin{array}{c}\text { Insulation } \\
\text { Resistance }\end{array}$ & $\begin{array}{c}\text { Lead } \\
\text { Resistance }\end{array}$ \\
\hline 0043 & Cable 2 & Lead to ground \\
0044 & Cable 3 & Lead to ground \\
0045 & Cable 3 & Lead to ground \\
0046 & Cable 4 & Lead to ground \\
0047 & Cable 4 & Lead to ground \\
$0048(a)$ & Instrumentation & Lead to lead & \\
$0049(a)$ & cable only & Instrumentation & Lead to lead \\
& cable only & Instrumentation & Lead to shield \\
& cable only & & \\
\end{tabular}

(a) Periodic check measurements. 


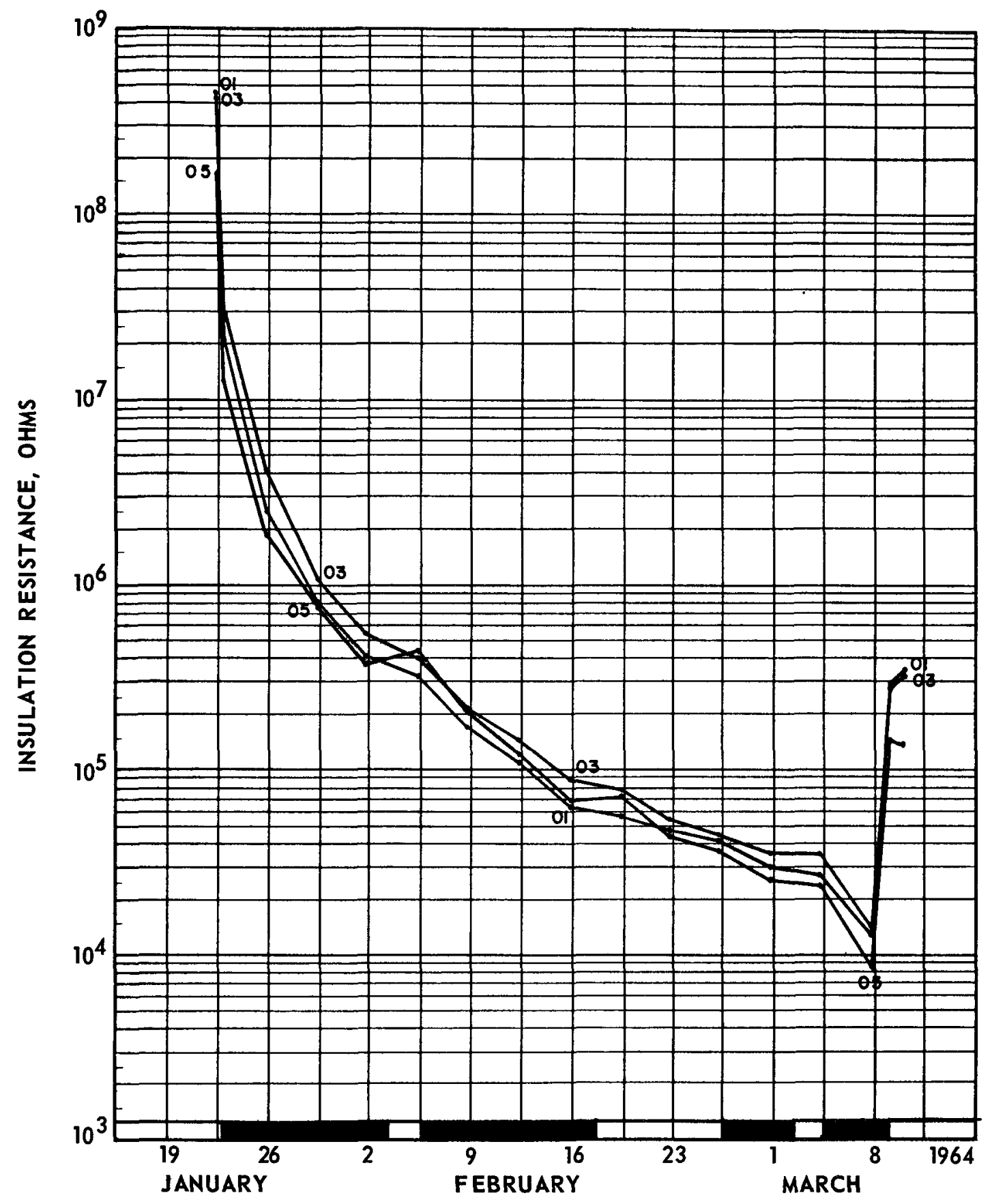

FIGURE 11. INSULATION RESISTANCES OF SELECTED LEADS TO GROUND IN CABLE HARNESS 100 IN EXPERIMENT HF-6 


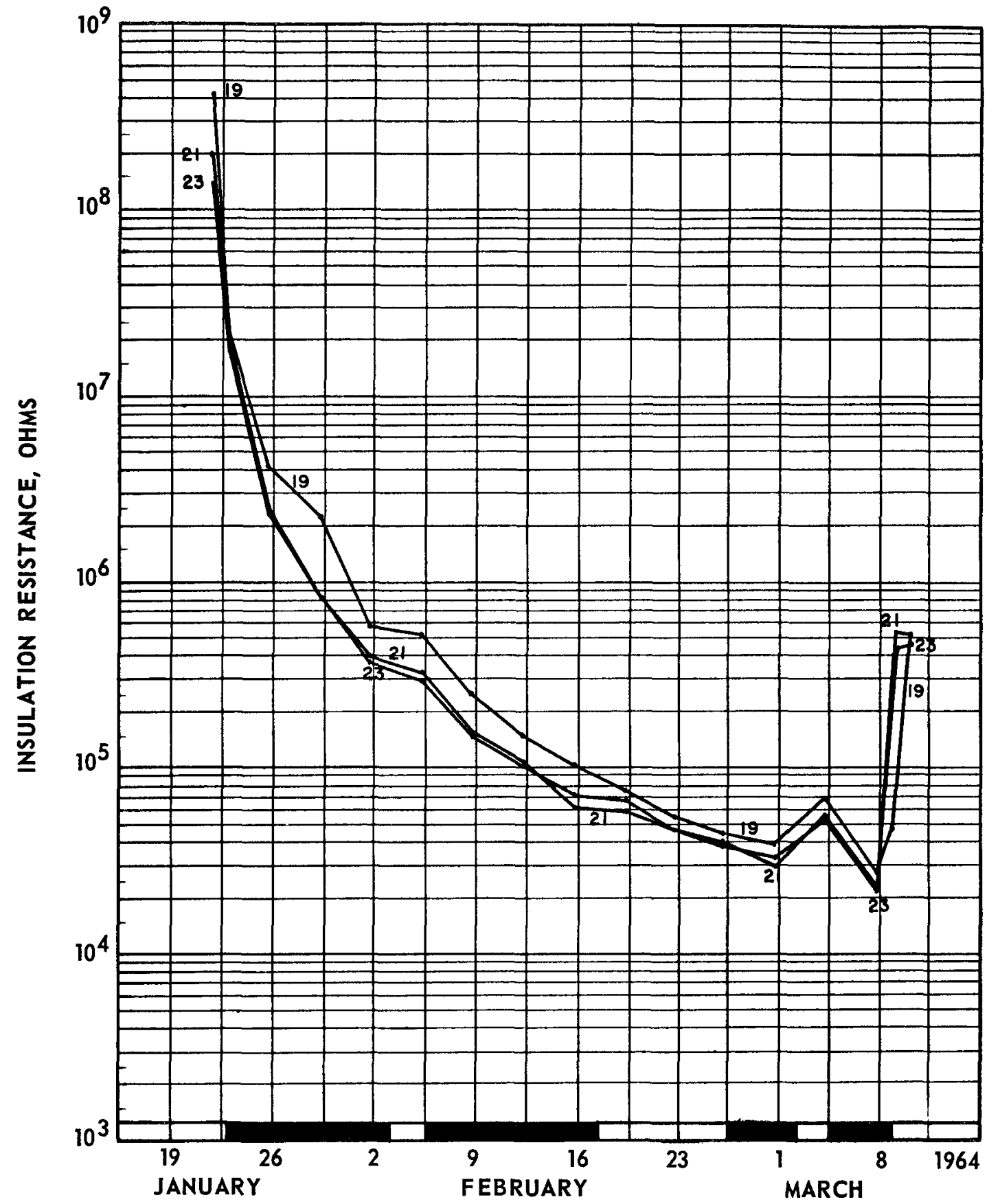

FIGURE 12. INSULATION RESISTANCES BETWEEN SELECTED LEAD PAIRS IN CABLE HARNESS 100 IN EXPERIMENT HF-6 


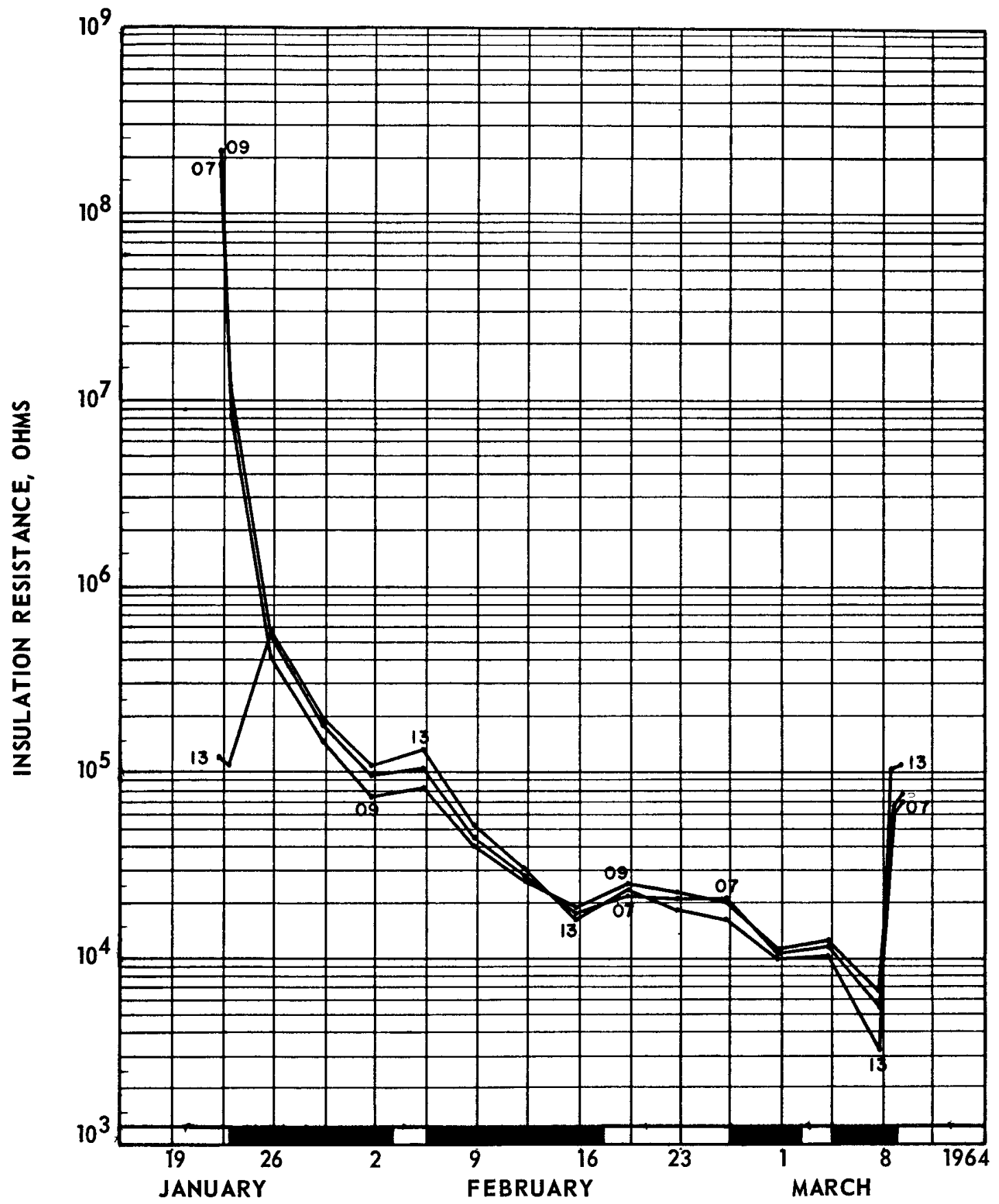

FIGURE 13. INSULATION RESISTANCES OF SELECTED LEADS TO GROUND IN CABLE HARNESS 106 IN EXPERIMENT HF-6 


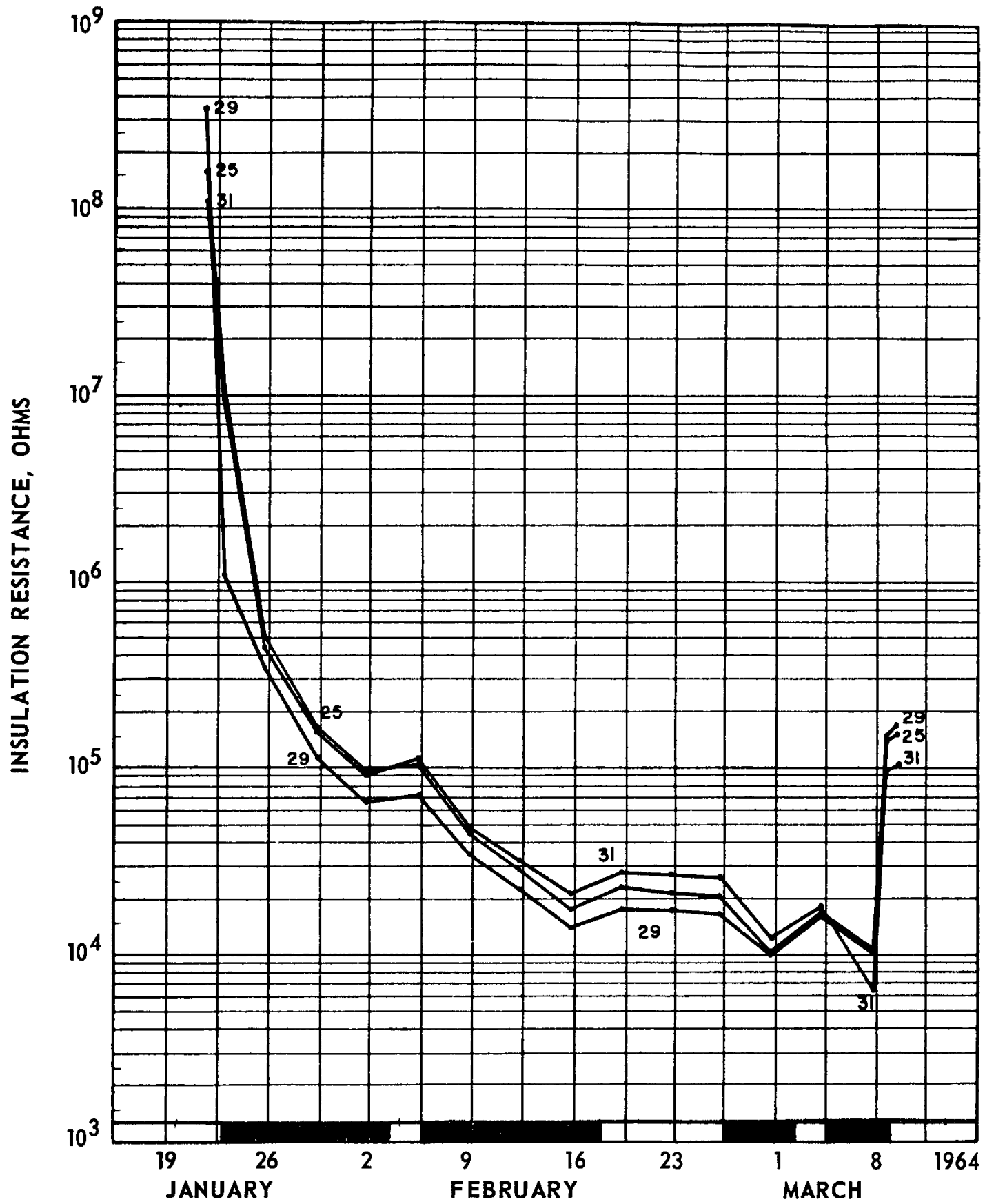

FIGURE 14. INSULATION RESISTANCE BETWEEN SELECTED LEAD PAIRS IN CABLE HARNESS 106 IN EXPERIMENT HF-6 


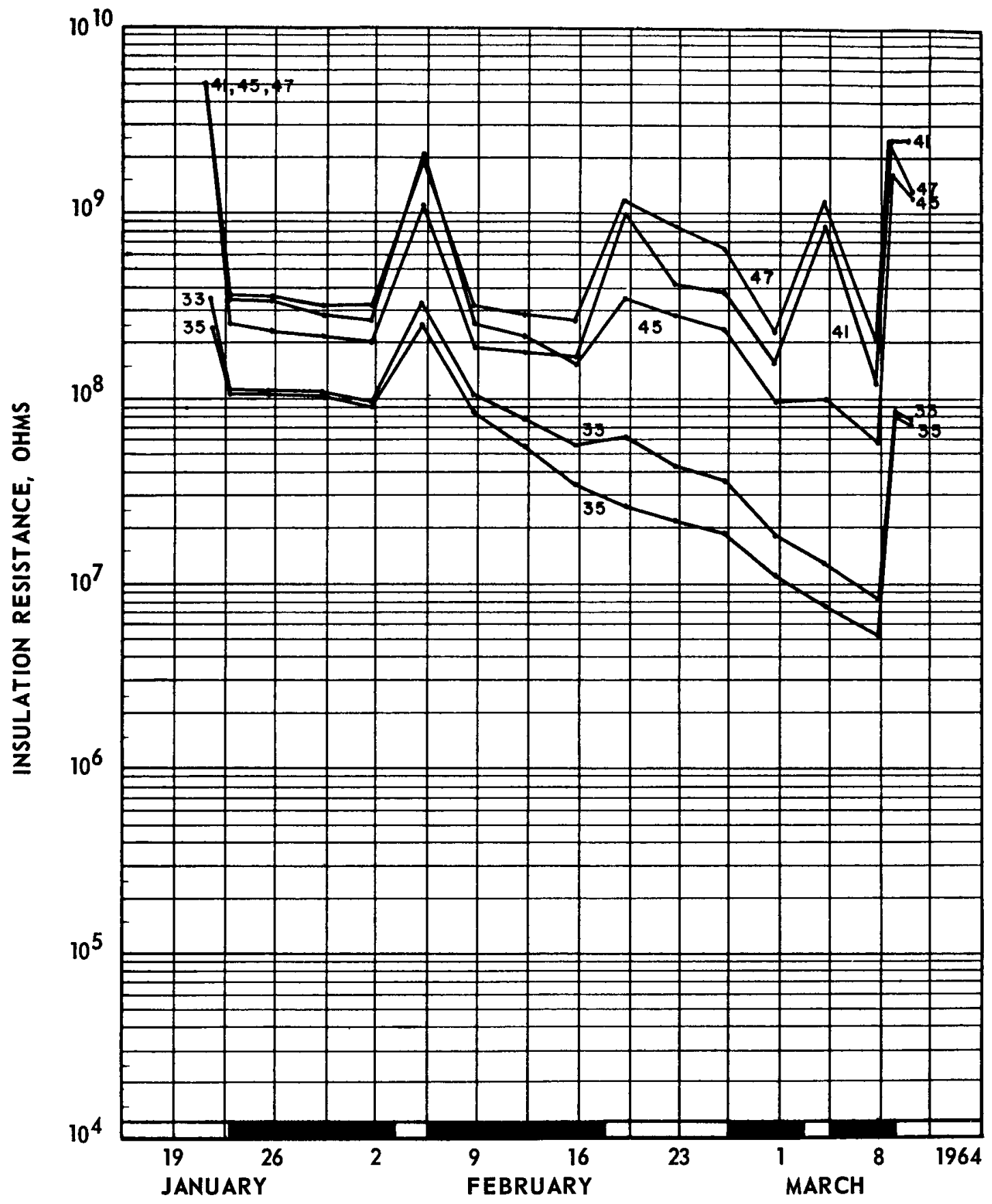

FIGURE 15. INSULATION RESISTANCES OF SELECTED LEADS TO GROUND FOR CABLE SAMPLES IN EXPERIMENT HF-6 


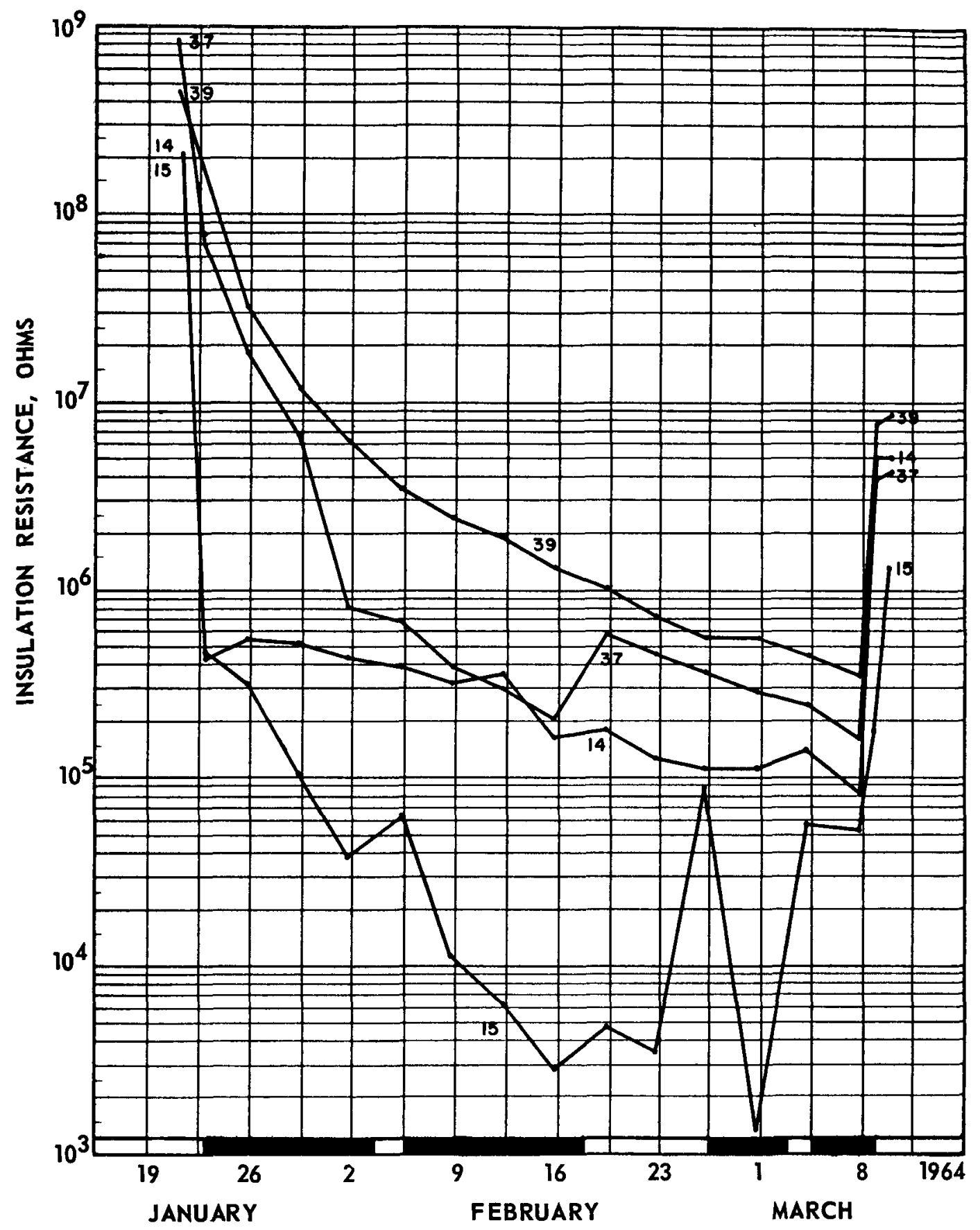

FIGURE 16. INSULATION RESISTANCES OF SWITCHES AND CONNECTOR SAMPLES IN EXPERIMENT HF-6 


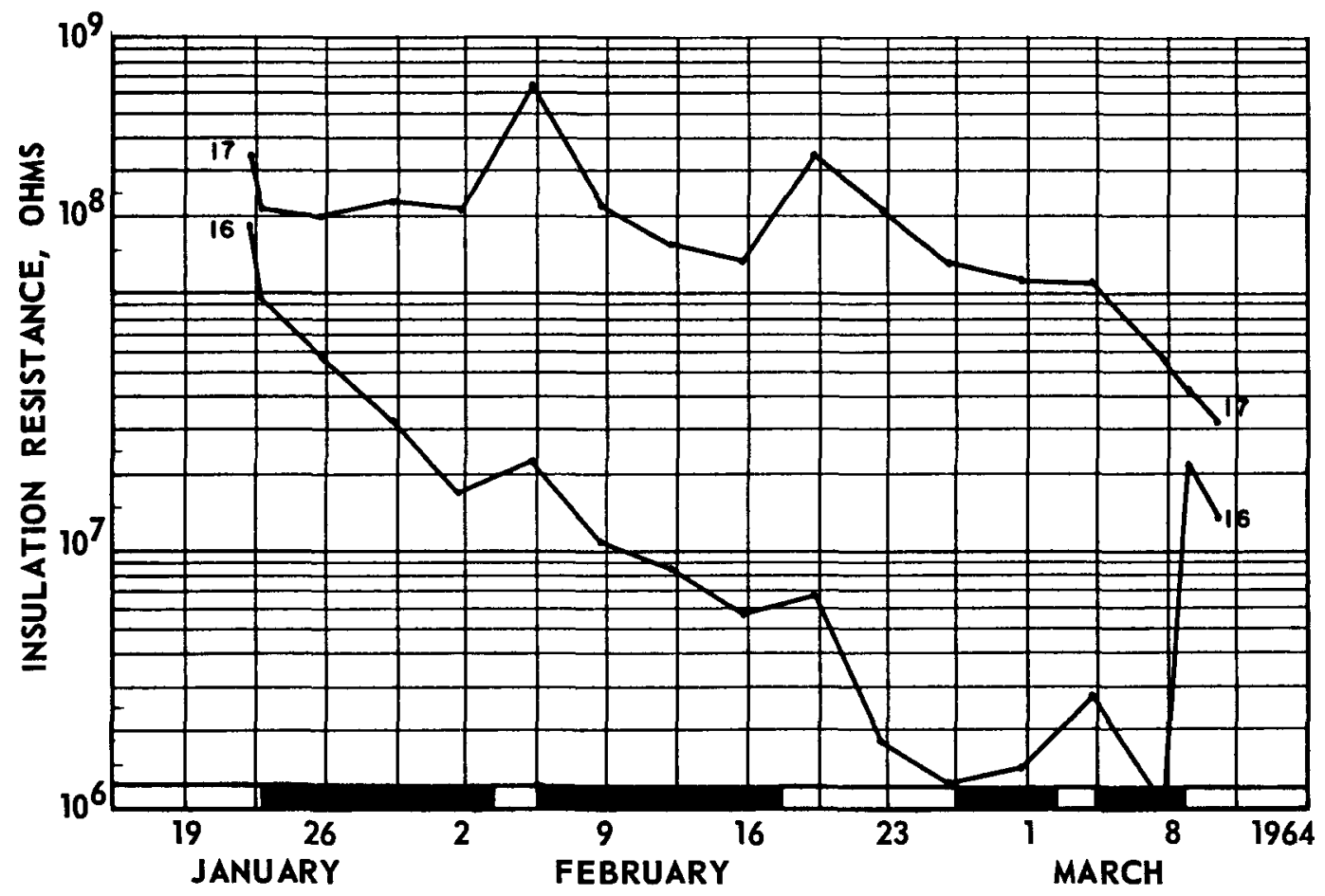

FIGURE 17. INSULATION RESISTANCES OF DUMMY TEST LEADS IN EXPERIMENT HF-6 


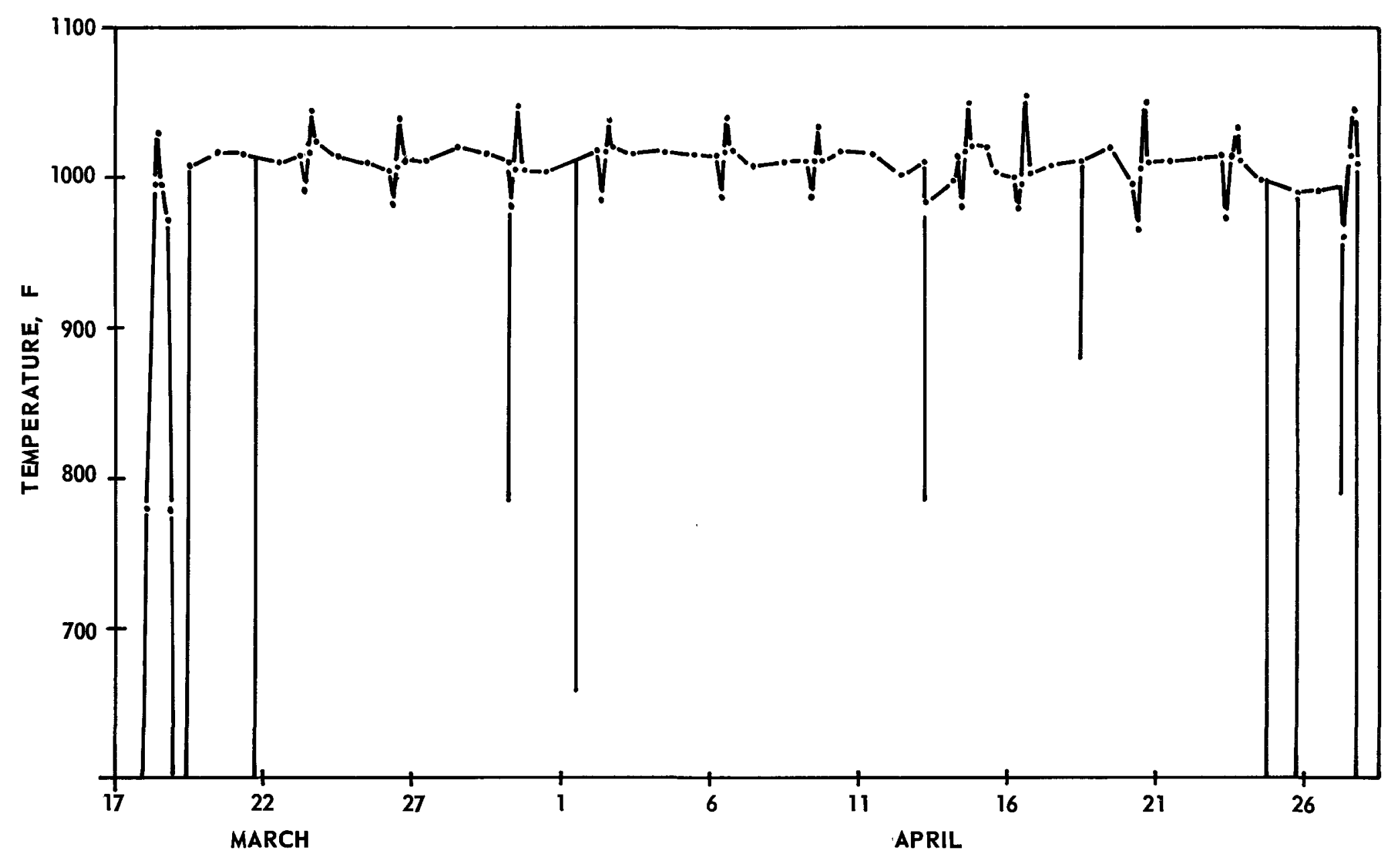

FIGURE 18. REPRESENTATIVE INTERNAL THERMOCOUPLE TEMPERATURE IN RTD 119 IN EXPERIMENT HF-7 
EABRD NO. 2

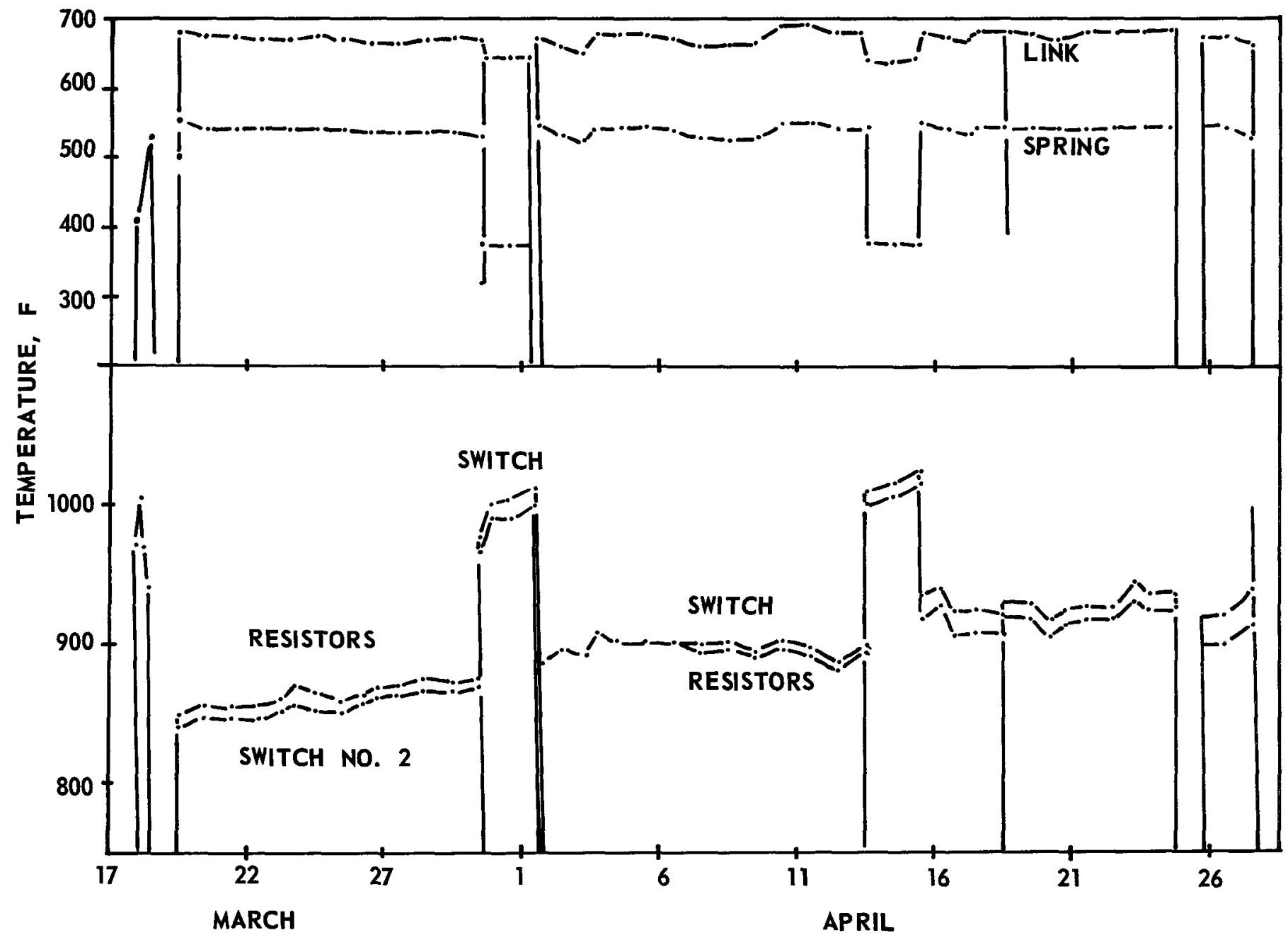

FIGURE 19. TYPICAL SPECIMEN TEMPERATURES IN EXPERIMENT HF-7 
TABLE 4. SUMMARY OF SPECIMEN TEMPERATURES IN EXPERIMENT HF -7

\begin{tabular}{|c|c|c|c|}
\hline \multirow[b]{2}{*}{ Sample } & \multicolumn{3}{|c|}{ Average Temperature, $F$, and Limits } \\
\hline & Cycle 153 & Cycle 154 & Cycle 155 \\
\hline \multicolumn{4}{|l|}{ RTD 107} \\
\hline Internal & $1005 \pm 10$ & $1005 \pm 15$ & $1000 \pm 15$ \\
\hline OD of case & $1005 \pm 15$ & $1030 \pm 10$ & $1050 \pm 15$ \\
\hline Connector & $870 \pm 10$ & $900 \pm 20$ & $915 \pm 10$ \\
\hline \multicolumn{4}{|l|}{ RTD 119} \\
\hline Internal & $1015 \pm 10$ & $1015 \pm 10$ & $1010 \pm 10$ \\
\hline OD of case & $965 \pm 5$ & $965 \pm 15$ & $960 \pm 10$ \\
\hline Connector & $830 \pm 5$ & $835 \pm 15$ & $840 \pm 10$ \\
\hline \multicolumn{4}{|l|}{ EABRD 1} \\
\hline Link & $640 \pm 5$ & $635 \pm 15$ & $650 \pm 10$ \\
\hline Large clevis & $645 \pm 5$ & $650 \pm 20$ & $655 \pm 10$ \\
\hline Small clevis & $680 \pm 5$ & $685 \pm 15$ & $690 \pm 10$ \\
\hline Spring & $510 \pm 10$ & $510 \pm 10$ & $510 \pm 5$ \\
\hline \multicolumn{4}{|l|}{ EABRD 2} \\
\hline Link & $670 \pm 5$ & $670 \pm 20$ & $680 \pm 10$ \\
\hline Large clevis & $680 \pm 10$ & $680 \pm 20$ & $690 \pm 10$ \\
\hline Small clevis & $715 \pm 10$ & $715 \pm 15$ & $720 \pm 10$ \\
\hline Spring & $540 \pm 10$ & $535 \pm 10$ & $520 \pm 5$ \\
\hline Resistors & $865 \pm 10$ & $895 \pm 15$ & $915 \pm 15$ \\
\hline Switch 1 & $800 \pm 10$ & $830 \pm 10$ & $855 \pm 10$ \\
\hline Switch 2 & $855 \pm 10$ & $900 \pm 15$ & $930 \pm 10$ \\
\hline Switch 3 & $645 \pm 5$ & $630 \pm 15$ & $620 \pm 10$ \\
\hline
\end{tabular}


The resistor board and limit switches were irradiated at 800 to $900 \mathrm{~F}$. However, during scheduled reactor shutdown periods, the temperatures of these specimens were increased about $100 \mathrm{~F}$ when additional electrical heat was needed to maintain the RTD's at temperature.

\section{System Vacuum}

During the initial pumpdown, the vacuum levels were in the $10^{-4}$ tor $r$ range. The vacuum level decreased from $10^{-4}$ torr to $10^{-5}$ torr during Cycle 153 (the first cycle of operation). The average vacuum level for the last two cycles was $1 \times 10^{-5}$ torr. The vacuum levels a re plotted in Figure 20.

On the second day of Cycle 153, the power cord to the diffusion pump shorted to ground, and instrument and heater power was lost for $1 / 2 \mathrm{hr}$. While repairs were being made, the system pressure rose into the micron range. The experiment remained inpile during this period. After $1-1 / 2 \mathrm{hr}$, normal pumping was resumed and temperatures were returned to normal operating levels. The ionization gage at the pump failed and the alternate gage was monitored for the remainder of the experiment.

On the seventh day of the final cycle, building water pressure was interrupted for 15 min. The diffusion pump overheated, as reflected in subsequent increased liquidnitrogen usage, but ultimate system vacuum was unaffected. Two days later, the main power line to the reactor site failed, with the subsequent interruption of all operations for a period of $12 \mathrm{hr}$. The manual valve on the roughing pump was closed immediately. When electric service was restored, the forepump would not evacuate the system properly. A replacement forepump was installed but difficulties in attaining good vacuum were still encountered. The diffusion pump was dismantled and cleaned with the associated complete loss of system vacuum. When pumping was resumed and a vacuum of $10^{-4}$ tor $r$ was achieved, the irradiation was resumed and specimen temperatures were restored to operating levels. Liquid-nitrogen consumption also returned to its original rate.

Electrical Measurements

The measurement circuits were the same as those described for the HF-6 experiment. Voltage measurements from the EABRD transducer-translator circuitry were made with the four-wire measuring circuit, using only the potential leads.

The RTD resistance measurements were performed using the four-wire circuit as far as the irradiation capsule header plate. Measurements between Points $A$ and $B$ (see Table 5) included the RTD temperature-sensing element and the lead resistances from the header plate to the RTD unit. Measurements between Points $B$ and $C$ were made to determine the lead resistances. The (AB) measurement minus the ( $B C)$ measurement gave the resistance of the temperature-sensing element only.

Measurements were made twice daily, 7 days a week for the entire irradiation, with the exceptions noted in the sections on RTD thermal cycling and EABRD actuation. The ir radiation specimen performance measurements are identified by the scanner point number in Table 5. 


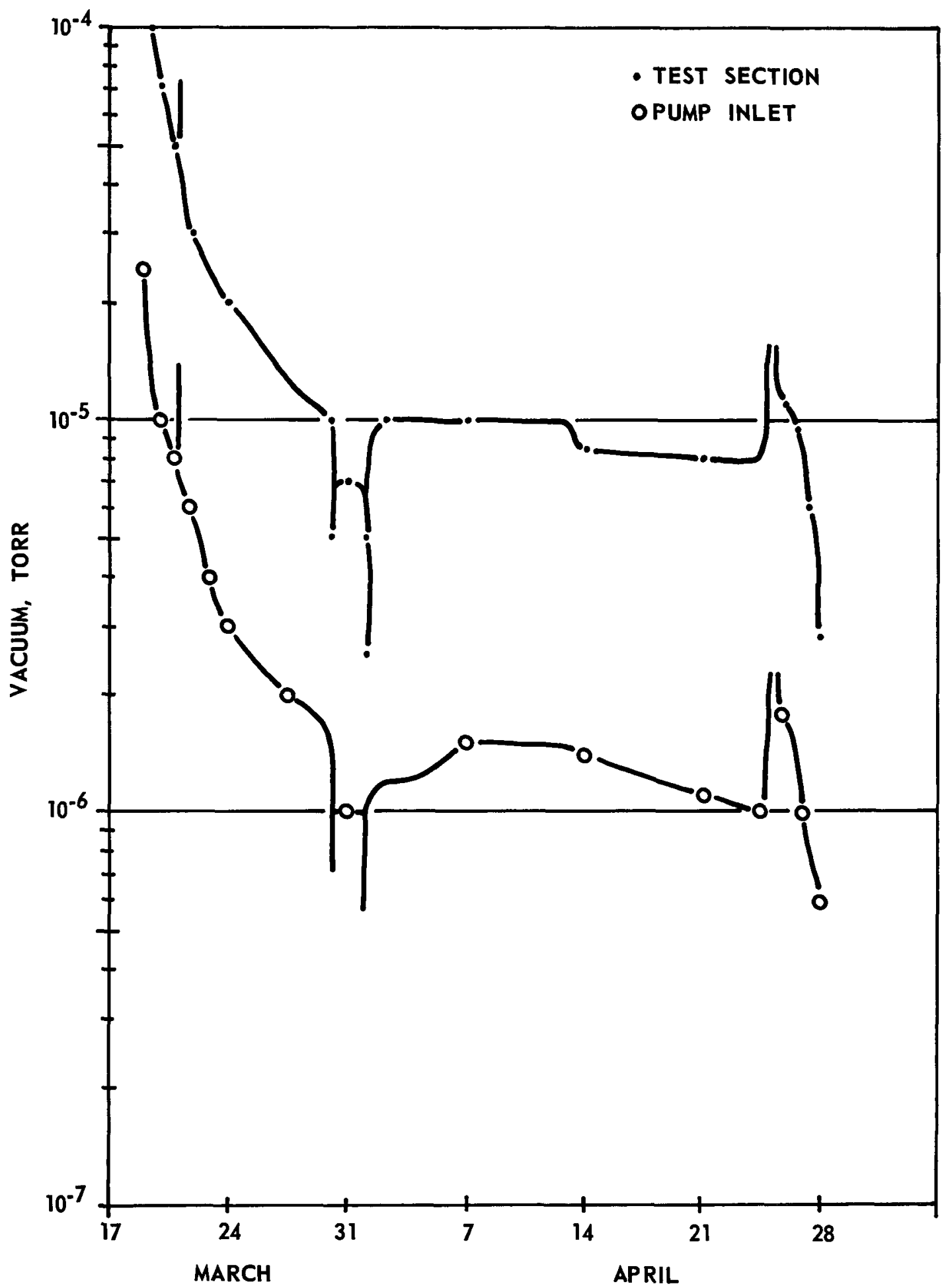

FIGURE 20. VACUUM LEVELS MONITORED IN EXPERIMENT HF-7 
TABLE 5. IDENTIFICATION OF SPECIMEN PERFORMANCE MEASUREMENTS IN EXPERIMENT HF-7

\begin{tabular}{|c|c|c|c|}
\hline $\begin{array}{l}\text { Scanner } \\
\text { Points }\end{array}$ & Specimen & $\begin{array}{c}\text { Insulation } \\
\text { Resistance }\end{array}$ & Resistance \\
\hline 0000 & RTD 107 & Pt. A to ground & Pts. A to $B$ \\
\hline 0001 & $\operatorname{RTD} 107$ & & Pts. B to $C$ \\
\hline 0002 & RTD 119 & Pt. A to ground & Pts. A to $B$ \\
\hline 0003 & RTD 119 & & Pts. B to C \\
\hline 0004 & EABRD 1 heater & Pt. A to ground & Pts. A to B \\
\hline 0005 & EABRD 2 heater & Pt. A to ground & Pts. A to $B$ \\
\hline 0006 & Switch 2 & $\begin{array}{l}\text { Open contact to } \\
\text { common }\end{array}$ & $\begin{array}{l}\text { Closed contact } \\
\text { to common }\end{array}$ \\
\hline 0007 & Resistor 2 & Common to ground & $\mathrm{R} 2$ to common \\
\hline 0008 & Resistor 3 & & R 3 to common \\
\hline 0009 & Resistor 4 & & $\mathrm{R} 4$ to common \\
\hline 0010 & Resistor 5 & & R 5 to common \\
\hline 0011 & Resistor 6 & & $\mathrm{R} 6$ to common \\
\hline 0012 & Resistor 7 & & $\mathrm{R} 7$ to common \\
\hline 0013 & Resistor 8 & & $\mathrm{R} 8$ to common \\
\hline 0014 & Resistor 9 & & $\mathrm{R} 9$ to common \\
\hline 0015 & Resistor 10 & & R 10 to common \\
\hline 0016 & Internal test $(a)$ & Lead to lead & \\
\hline 0017 & External test(b) & Feedthrough to ground & \\
\hline 0018 & EABRD 1 transducer & Lead to ground & \\
\hline 0019 & EABRD 2 transducer & Lead to ground & \\
\hline 0020 & External test $(c)$ & Lead to ground & \\
\hline 0021 & External test(c) & Lead to ground & \\
\hline 0022 & RTD 107 & & Pts. A to $C$ \\
\hline 0023 & RTD 119 & & Pts. A to $\mathrm{C}$ \\
\hline 0024 & Translator 1086 & Voltage-output measur & ement EABRD 2 \\
\hline 0025 & Translator 1087 & Voltage-output measur & ement EABRD 1 \\
\hline
\end{tabular}

(a) Insulation-resistance measurement of a pair of leads extending to the specimen area in the irradiation capsule.

(b) Insulation-resistance measurement of a feedthrough in the capsule header plate.

(c) Insulation-resistance measurement of instrumentation leads down to the header plate, but not connected at the header plate. 
During the HF-7 irradiation, selected scanner points were continuously plotted for the purpose of maintaining experiment surveillance. Typical insulation resistance data are plotted in Figure 21.

In Figure 22, three curves are shown, representing the median, and the upper and lower extreme values of resistance for the nine test resistors. The vertical lines show the limits for the seven intermediate resistance values. The two drops in the lower extreme value occurred during reactor shutdowns.

\section{$\underline{\text { RTD Thermal Cycling }}$}

To obtain calibration data from the RTD platinum elements as the irradiation progressed, four periodic thermal-cycling experiments were conducted during each reactor cycle; one of these cycling experiments was conducted during the scheduled cycle shutdown. The following procedure was used when the reactor was at power:

(1) The sensor resistance and six internal-thermocouple outputs were monitored at the nominal $1010 \mathrm{~F}$ operating temperature.

(2) The temperature was decreased to a nominal $980 \mathrm{~F}$ and stabilized before the same measurements were repeated.

(3) The temperature was subsequently changed to $1010 \mathrm{~F}, 1040 \mathrm{~F}$, and $1010 \mathrm{~F}$ again, and measurements were made at each step when temperatures were stable.

Preirradiation and between cycle, thermal-cycling data were taken as follows:

(1) Sensor and thermocouple data were obtained at the nominal but stable $1010 \mathrm{~F}$.

(2) The RTD heaters were turned off. As the zinc bath cooled, its temperature was monitored continually by the internal thermocouples into the isotherm (approximately $787 \mathrm{~F}$ ). The isotherm was observed for durations of 20 to $30 \mathrm{~min}$ and the resistance of the sensor was monitored near the end of the isotherm.

(3) The heaters were turned on and additional data were obtained as outlined in Items 2 and 3 above.

The cycling procedure was altered slightly during the last cycle; measurements were made at 1010,980, 1000, 1020, 1040, and $1010 \mathrm{~F}$ nominal temperatures. The isotherm was established at the end of the irradiation and the elements were thermally cycled with the same temperature schedule.

The results of the isotherm experiments are presented in Table 6. The isotherm experiment at the end of the irradiation was conducted while the reactor was at $215 \mathrm{kw}$. The measuring circuit for the RTD 107 element failed in the middle of the second cycle. (Hot-cell examination showed that the graphite crucible had cracked and the zinc had shorted the measurement leads.) During irradiation periods, the RTD element indicated a higher temperature than did the thermocouple, as was expected owing to internal heating from gamma radiation. Between reactor cycles, the thermocouple indicated a higher temperature than did the RTD element. 


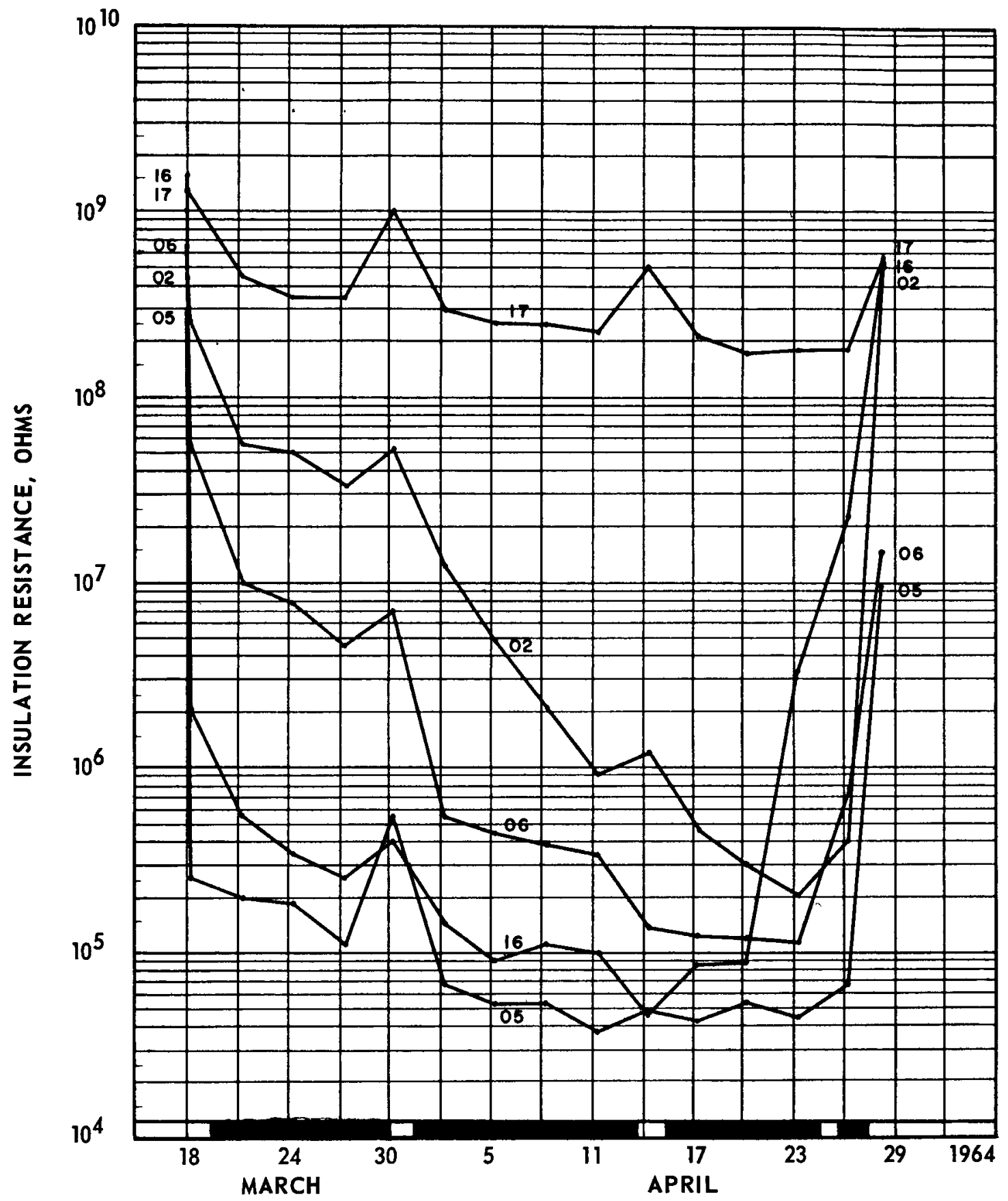

FIGURE 21. INSULATION RESISTANCES OF SELECTED SPECIMENS IN EXPERIMENT HF-7 


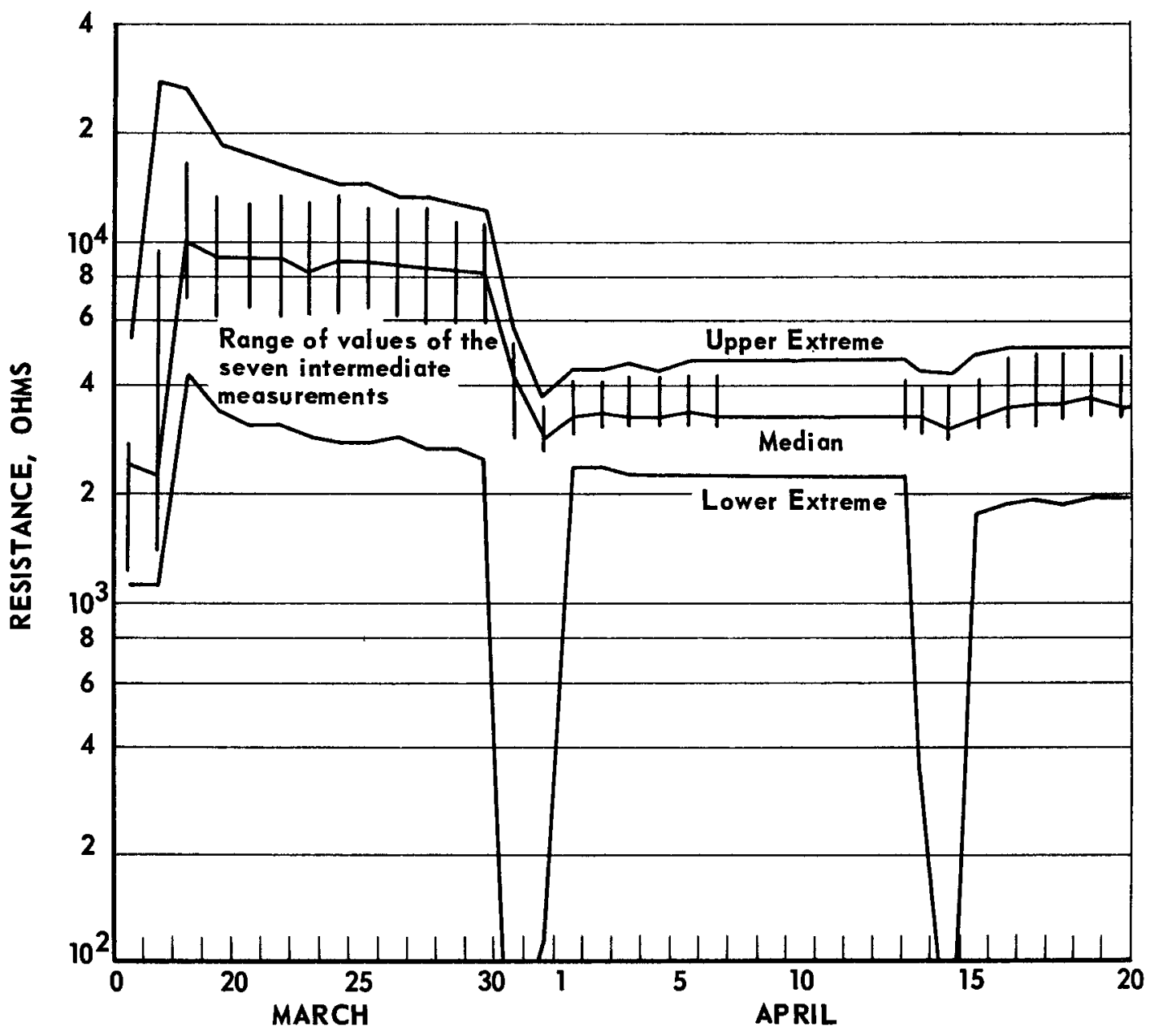

FIGURE 22. RESISTANCES MEASURED IN EXPERIMENT HF-7 
TABLE 6. SUMMARY OF RESULTS OF PLATINUM

SENSOR-ISOTHERM EXPERIMENTS

\begin{tabular}{ccccc}
\hline \hline $\begin{array}{c}\text { Accumulated } \\
\text { Time In-Pile, } \\
\text { hr }\end{array}$ & $\begin{array}{c}\text { Resistance, } \\
\text { ohms }\end{array}$ & $\begin{array}{c}\text { Temperature, } \\
\text { F }\end{array}$ & $\begin{array}{c}\text { Resistance, } \\
\text { ohms }\end{array}$ & $\begin{array}{c}\text { Temperature, } \\
\text { F }\end{array}$ \\
\hline 0 & 120.5 & 785 & 122.6 & 783 \\
262 & 119.8 & 790 & 122.0 & 764 \\
553 & 121.7 & 787 & -- & 746 \\
820 & 124.5 & 785 & -- & 725 \\
\hline
\end{tabular}

\section{EABRD Actuation}

Data obtained from the EABRD transducer-translator output was regularly forwarded to Atomics International. At the end of the irradiation, it was specified that one of the EABRD links be actuated while in a specified gamma flux of $1.8 \times 10^{6} \mathrm{R} / \mathrm{hr}$ (equivalent to $215-\mathrm{kw}$ reactor power) at a link temperature of $500 \mathrm{~F}$. A Moseley recorder was set up to monitor Translator 1087 (EABRD 1). A dual-channel Sanborn recorder was used to measure the power consumed while actuating the link heater. The power was supplied by a $12-\mathrm{v} d-\mathrm{c}$ storage battery and the current peaked at $4.95 \mathrm{amp}$. Both recorders were operated with a fast chart speed and heater power was left on until evidence of link separation was observed. The time of firing monitored by the two recorders agreed within 0.7 per cent.

The power trace was measured by a planimeter and by step integration, and yielded $811.935 \mathrm{w}-\mathrm{sec}$ (the time to actuate was $18.57 \mathrm{sec}$ ).

POSTIRRADIATION DOSIMETRY

$\underline{\text { In-pile Measurement Techniques and Data }}$

The neutron and gamma exposures actually received by the specimens were determined from a series of postirradiation analyses involving data obtained during both mock-up and in-pile operations.

The actual neutron exposures were measured by two types of wire dosimeters attached to the test specimens. These wires were recovered at the Battelle hot cell and returned to the research reactor for analysis. Iron wire dosimeters were used for fast-neutron exposures, using the Fe-54 (n, p) Mn-54 threshold reaction. The resultant threshold exposures were corrected to exposures above $0.1 \mathrm{Mev}$ and above $0.5 \mathrm{Mev}$ using the fast-neutron energy-spectrum data obtained in mock-up dosimetry.

Cobalt-aluminum wire dosimeters $(0.1 \mathrm{w} / \mathrm{o}$ cobalt) were used for thermal-neutron exposures. The total activities of the dosimeters were corrected to thermal-neutron activations by use of the cadmium ratios for cobalt as determined from mock-up measurements. 
Resonance neutron exposures were calculated from the fast exposures, applying ratios of resonance- to fast-neutron fluxes as measured simultaneously in the mock-up chamber, at the positions occupied by the test specimens.

Accumulated gamma exposures were found from the mock-up measurements of the gamma exposure rates at the positions of the test specimens and the irradiation time.

The exposures of the principal test specimens of Experiments $\mathrm{HF}-6$ and $\mathrm{HF}-7$ as determined by the se methods are given in the Appendix.

\section{Summary of Results}

The neutron and gamma exposures specified, anticipated, and actually received for Experiments HF-6 and HF-7 are compared in Table 7. Specified exposures are as stated by Atomics International. Anticipated exposures are results of mock-up dosimetry, based on irradiation-exposure-rate distributions, specimen locations in the test chamber, and maximum expected irradiation times. Received exposures are average values taken over all in-pile dosimeters associated with the specimens reported. Fast-neutron exposures received were generally below the specifications, although the test chamber was positioned in a region of maximum fast flux. Thermal-neutron and gamma exposures received generally exceeded those specified. An additional fuel element would have increased the fast flux, but the resultant gamma exposure rate could not have been tolerated by some of the specimens.

For Experiment HF-6, neutron exposures of individual specimens varied within about \pm 40 per cent of the average exposure reported in Table 7 . The variations resulted from placement of the specimens over a 16-in. axial span of the test chamber where flux gradients were inherent.

TABLE 7. SUMMARY OF ENVIRONMENTS FOR EXPERIMENTS HF-6 AND HF -7

\begin{tabular}{|c|c|c|c|c|}
\hline \multirow{2}{*}{$\begin{array}{c}\text { Experiment, } \\
\text { Specimen }\end{array}$} & \multirow[b]{2}{*}{ Radiation Type } & \multicolumn{3}{|c|}{ Exposures } \\
\hline & & Specified & Anticipated & Received \\
\hline $\mathrm{HF}-6, \mathrm{All}$ & $\begin{array}{l}\text { Fast Neutrons, } \mathrm{n} / \mathrm{cm}^{2} \\
\text { Thermal Neutrons, } \mathrm{n} / \mathrm{cm}^{2} \\
\text { Gamma, } \mathrm{R}\end{array}$ & $\begin{array}{l}1.5 \times 10^{19} \\
1.8 \times 10^{18} \\
1.5 \times 10^{10}\end{array}$ & $\begin{array}{l}7.5 \times 10^{18} \\
2.1 \times 10^{18} \\
2.3 \times 10^{10}\end{array}$ & $\begin{array}{l}5.7 \times 10^{18} \\
1.8 \times 10^{18} \\
2.2 \times 10^{10}\end{array}$ \\
\hline $\mathrm{HF}-7, \mathrm{EABRD}$ & $\begin{array}{l}\text { Fast Neutrons, } \mathrm{n} / \mathrm{cm}^{2} \\
\text { Thermal Neutrons, } \mathrm{n} / \mathrm{cm}^{2} \\
\text { Gamma, } \mathrm{R}\end{array}$ & $\begin{array}{l}1.5 \times 10^{19} \\
1.8 \times 10^{18} \\
1.5 \times 10^{10}\end{array}$ & $\begin{array}{l}8.8 \times 10^{18} \\
2.2 \times 10^{18} \\
2.6 \times 10^{10}\end{array}$ & $\begin{array}{l}8.3 \times 10^{18} \\
2.4 \times 10^{18} \\
2.1 \times 10^{10}\end{array}$ \\
\hline $\mathrm{HF}-7, \mathrm{RTD}$ & $\begin{array}{l}\text { Fast Neutrons, } \mathrm{n} / \mathrm{cm}^{2} \\
\text { Thermal Neutrons, } \mathrm{n} / \mathrm{cm}^{2} \\
\text { Gamma, } \mathrm{R}\end{array}$ & $\begin{array}{l}5.0 \times 10^{18} \\
6.0 \times 10^{17} \\
1.0 \times 10^{10}\end{array}$ & $\begin{array}{l}4.0 \times 10^{18} \\
1.2 \times 10^{18} \\
1.6 \times 10^{10}\end{array}$ & $\begin{array}{l}4.7 \times 10^{18} \\
1.6 \times 10^{18} \\
1.6 \times 10^{10}\end{array}$ \\
\hline
\end{tabular}


For Experiment HF-7, neutron exposures of parts in the two electrically actuated band-release devices (EABRD) varied within \pm 15 per cent, while components of the two resistance-temperature detectors (RTD) varied within about \pm 60 per cent of the exposures reported in Table 7. These variations resulted from flux attenuations in the devices; the RTD was three times more massive than the EABRD. The average fastneutron exposure received by the two EABRD's was 45 per cent below that requested, and the exposures of the prime components (the links) were 35 per cent low. The average fast-neutron exposure received by the two RTD's was 6 per cent below that requested, though the exposures incident upon the parts facing the BRR core were 25 per cent greater than specified. 
APPENDIX

RADIATION EXPOSURES OF INDIVIDUAL COMPONENTS OF EXPER IMENTS HF-6 AND HF-7 


\section{APPENDIX}

RADIATION EXPOSURES OF INDIVIDUAL COMPONENTS

OF EXPERIMENTS HF-6 AND HF-7

The neutron and gamma exposures of the individual components are listed in Tables A- 1 and A-2. The neutron exposures are broken down into four groups: Group I is the thermal-neutron exposure ( 0 to $0.4 \mathrm{ev})$; Group II is the resonance-neutron exposure $(0.4 \mathrm{ev}$ to $1 \mathrm{Mev})$; Group III is the fast-neutron exposure from 0.1 to $0.5 \mathrm{Mev}$ and was obtained by subtracting the fast-neutron exposure above $0.5 \mathrm{Mev}$ from the total fast exposure; and Group IV is the fast-neutron exposure above $0.5 \mathrm{Mev}$. 
TABLE A-1. EXPERIMENT HF-6 NEUTRON AND GAMMA EXPOSURES

\begin{tabular}{lccccrr}
\hline \multicolumn{1}{c}{ Specimen } & Zone & $\begin{array}{c}\text { Group I, } \\
10^{18} \mathrm{n} / \mathrm{cm}^{2}\end{array}$ & $\begin{array}{c}\text { Group II, } \\
10^{18} \mathrm{n} / \mathrm{cm}^{2}\end{array}$ & $\begin{array}{c}\text { Group III, } \\
10^{17} \mathrm{n} / \mathrm{cm}^{2}\end{array}$ & $\begin{array}{c}\text { Group IV, } \\
10^{18} \mathrm{n} / \mathrm{cm}^{2}\end{array}$ & $\begin{array}{r}\text { Gamma Ex } \\
10^{10} \mathrm{R}\end{array}$ \\
Cable Harness 100 & & & & & & \\
19-pin connector & $3-\mathrm{B}$ & 1.57 & & & & \\
Cables & $3-\mathrm{B}$ & 1.78 & 6.5 & 4.16 & 3.04 & 1.52 \\
Cables & $3-\mathrm{A}$ & 2.21 & 7.1 & 5.05 & 3.69 & 1.75 \\
19-pin connector & $3-\mathrm{A}$ & 1.61 & 7.5 & 5.96 & 4.36 & 2.06 \\
Cables & 2 & 6.8 & 4.53 & 3.31 & 1.71 \\
2-pin connector & 2 & 1.72 & 7.8 & 5.80 & 4.24 & 1.88 \\
4-pin connector & 2 & 1.64 & 7.0 & 5.73 & 4.19 & 2.14 \\
6-pin connector & 2 & 2.19 & 9.2 & 8.55 & 6.25 & 2.92 \\
Single conductor lug & 2 & 1.83 & 7.0 & 6.08 & 4.44 & 2.33 \\
Cables & 1.72 & 7.1 & 5.82 & 4.26 & 2.34 \\
& $1-\mathrm{B}$ & 1.96 & 7.3 & 5.96 & 4.35 & 2.36 \\
& $1-\mathrm{A}$ & 1.94 & 7.3 & 5.87 & 4.29 & 2.22
\end{tabular}

Cable Harness 106

$\begin{array}{lccrrrr}\text { 19-pin connector } & \text { 3-B } & 1.79 & 7.4 & 6.97 & 5.30 & 1.98 \\ \text { Cables } & 3-\mathrm{B} & 1.56 & 7.9 & 6.05 & 4.42 & 1.71 \\ \text { Cables } & 3-\mathrm{A} & 1.72 & 8.4 & 7.11 & 5.20 & 2.06 \\ \text { 19-pin connector } & \text { 3-A } & 2.00 & 8.7 & 9.25 & 6.84 & 2.33 \\ \text { Cables } & 2 & 2.10 & 9.3 & 8.97 & 6.55 & 2.65 \\ \text { 2-pin connector } & 2 & 2.00 & 12.1 & 10.12 & 7.40 & 2.94 \\ \text { 4-pin connector } & 2 & 1.81 & 8.3 & 6.09 & 4.45 & 2.17 \\ \text { 6-pin connector } & 2 & 1.79 & 10.2 & 8.01 & 5.85 & 2.38 \\ \text { Single connector lug } & 2 & 1.91 & 11.0 & 9.18 & 6.71 & 2.41 \\ \text { Cables } & 1-\mathrm{B} & 1.78 & 9.4 & 7.55 & 5.52 & 2.43 \\ & 1-\mathrm{A} & 1.70 & 10.0 & 7.94 & 5.81 & 2.27\end{array}$

Limit Switches

\begin{tabular}{|c|c|c|c|c|c|c|}
\hline Actuated & 2 & 1.84 & 8.2 & 6.87 & 5.03 & 1.76 \\
\hline Unactuated & 2 & 2.04 & 9.8 & 8.27 & 6.05 & 1.76 \\
\hline D-119 Connector & 2 & 2.06 & 7.8 & 7.70 & 5.63 & 2.82 \\
\hline D-133 Connector & 2 & 1.77 & 8.8 & 6.20 & 4.53 & 2.10 \\
\hline \multirow[t]{7}{*}{ Cables $A, 3$, and 4} & $3-B$ & 1.78 & 7.1 & 5.05 & 3.69 & 1.75 \\
\hline & $3-A$ & 2.21 & 7.5 & 5.96 & 4.36 & 2.06 \\
\hline & 2 & 1.85 & 7.4 & 6.46 & 4.73 & 2.05 \\
\hline & $1-B$ & 1.96 & 7.3 & 5.96 & 4.36 & 2.36 \\
\hline & $1-\mathrm{A}$ & 1.94 & 7.3 & 5.87 & 4.29 & 2.22 \\
\hline & $0-B$ & 1.63 & -- & 3.98 & 2.91 & 1.59 \\
\hline & $0-A$ & 0.95 & - & 1.73 & 1.27 & 0.83 \\
\hline \multirow{7}{*}{$\begin{array}{l}\text { Cables } B \text { (heat treated), } \\
1 \text { and } 2\end{array}$} & $3-B$ & 1.67 & 7.9 & 6.05 & 4.42 & 1.71 \\
\hline & $3-\mathrm{A}$ & 1.72 & 8.4 & 7.11 & 5.20 & 2.06 \\
\hline & 2 & 1.92 & 10.9 & 8.55 & 6.25 & 2.08 \\
\hline & $1-B$ & 1.78 & 9.4 & 7.55 & 5.52 & 2.43 \\
\hline & $1-A$ & 1.70 & 10.0 & 7.94 & 5.81 & 2.27 \\
\hline & $0-B$ & 1.50 & -- & 5.55 & 4.06 & 1.57 \\
\hline & $0-A$ & 0.89 & -- & 2.47 & 1.80 & 0.79 \\
\hline
\end{tabular}

(a) The test region was divided into seven zones as follows, to define the exposures received by various parts of those specimens which traversed several zones

$\begin{array}{cc}\text { Zone Designation } & \begin{array}{c}\text { Distance Above Bottom } \\ \text { of Test Chamber, in. }\end{array} \\ 3-\mathrm{B} & 1 \text { to } 4 \\ 3-\mathrm{A} & 4 \text { to } 7 \\ 2 & 7 \text { to } 11 \\ 1-\mathrm{B} & 11 \text { to } 14\end{array}$



Distance Above Bottom

of Test Chamber, in.

14 to 17

17 to 23

23 to 29 
TABLE A -2. EXPERIMENT HF -7 NEUTRON AND GAMMA EXPOSURES

\begin{tabular}{|c|c|c|c|c|c|}
\hline Specimen & $\begin{array}{c}\text { Group I, } \\
10^{18} \mathrm{n} / \mathrm{cm}^{2}\end{array}$ & $\begin{array}{c}\text { Group II, } \\
10^{18} \mathrm{n} / \mathrm{cm}^{2}\end{array}$ & $\begin{array}{c}\text { Group III, } \\
10^{17} \mathrm{n} / \mathrm{cm}^{2}\end{array}$ & $\begin{array}{c}\text { Group IV, } \\
10^{18} \mathrm{n} / \mathrm{cm}^{2}\end{array}$ & $\begin{array}{c}\text { Gamma Exposure, } \\
10^{10} \mathrm{R}\end{array}$ \\
\hline \multicolumn{6}{|l|}{ RTD 107} \\
\hline Upper Half & & & & & 1.12 \\
\hline Surface (total) & 1.01 & 4.4 & 3.9 & 2.82 & \\
\hline Front (core side) & 1.13 & 6.4 & 5.6 & 4.09 & \\
\hline Back (away from core) & 1.06 & 2.9 & 2.6 & 1.84 & \\
\hline Lower Half & & & & & 1.61 \\
\hline Surface (total) & 0.98 & 6.0 & 5.3 & 3.86 & \\
\hline Front (core side) & 1.52 & 8.9 & 7.8 & 5.69 & \\
\hline Back (away from core) & 0.75 & 3.4 & 2.9 & 2.17 & \\
\hline Connector & 2.48 & 10.1 & 8.8 & 6.46 & 2.01 \\
\hline \multicolumn{6}{|l|}{ RTD 119} \\
\hline Upper Half & & & & & 1.32 \\
\hline Surface (total) & 1.28 & 3.9 & 3.5 & 2.51 & \\
\hline Front (core side) & 1.90 & 5.9 & 5.2 & 3.75 & \\
\hline Back (away from core) & 0.69 & 2.0 & 1.7 & 1.26 & \\
\hline Lower Half & & & & & 1.62 \\
\hline Surface (total) & 1.73 & 5.5 & 4.8 & 3.51 & \\
\hline Front (core side) & 2.54 & 8.4 & 7.3 & 5.37 & \\
\hline Back (away from core) & 1.02 & 2.9 & 2.6 & 1.84 & \\
\hline Connector & 2.21 & 8.9 & 7.7 & 5.69 & 1.99 \\
\hline \multicolumn{6}{|l|}{ EABRD 1} \\
\hline Link & 2.85 & 13.1 & 11.3 & 8.30 & 2.12 \\
\hline Large clevis & 2.36 & 10.2 & 8.9 & 6.49 & 2.15 \\
\hline Small clevis & 2.41 & 10.7 & 9.2 & 6.74 & 2.09 \\
\hline Spring & 2.35 & 9.5 & 7.3 & 5.32 & 1.80 \\
\hline \multicolumn{6}{|l|}{ EABRD 2} \\
\hline Link & 2.44 & 13.9 & 12.0 & 8.79 & 2.15 \\
\hline Large clevis & 2.23 & 10.4 & 9.1 & 6.61 & 2.19 \\
\hline Small clevis & 2.36 & 11.1 & 9.5 & 6.93 & 2.12 \\
\hline Spring & 2.20 & 9.7 & 7.5 & 5.46 & 1.77 \\
\hline Resistors & 1.79 & 8.2 & 7.2 & 5.22 & 1.84 \\
\hline \multicolumn{6}{|l|}{ Limit Switches } \\
\hline Actuated & 1.42 & 2.3 & 2.0 & 1.45 & 1.11 \\
\hline Unactuated & 1.42 & 2.3 & 2.0 & 1.45 & 1.00 \\
\hline Push-Button Switch & 0.85 & 4.4 & 3.9 & 2.79 & 1.53 \\
\hline
\end{tabular}

